\title{
Gravin Orchestrates Protein Kinase A and $\beta 2$-Adrenergic Receptor Signaling Critical for Synaptic Plasticity and Memory
}

\author{
Robbert Havekes, ${ }^{1}$ David A. Canton, ${ }^{2 \star}$ Alan J. Park,,${ }^{1 *}$ Ted Huang, ${ }^{1 *}$ Ting Nie, ${ }^{1 \star}$ Jonathan P. Day, ${ }^{3}$ Leonardo A. Guercio, ${ }^{1}$ \\ Quinn Grimes, ${ }^{1}$ Vincent Luczak, ${ }^{1}$ Irwin H. Gelman, ${ }^{4}$ George S. Baillie, ${ }^{3}$ John D. Scott, ${ }^{2}$ and Ted Abel ${ }^{1}$ \\ 'Department of Biology, University of Pennsylvania, Philadelphia, Pennsylvania 19104, ${ }^{2}$ Howard Hughes Medical Institute, Department of Pharmacology, \\ University of Washington, School of Medicine, Seattle, Washington 98195-7280, ${ }^{3}$ Institute of Cardiovascular and Medical Science, College of Medical, \\ Veterinary and Life Sciences, University of Glasgow, Glasgow G12 8QQ, United Kingdom, and ${ }^{4}$ Department of Cancer Genetics, Roswell Park Cancer \\ Institute, Buffalo, New York 14263
}

\begin{abstract}
A kinase-anchoring proteins (AKAPs) organize compartmentalized pools of protein kinase A (PKA) to enable localized signaling events within neurons. However, it is unclear which of the many expressed AKAPs in neurons target PKA to signaling complexes important for long-lasting forms of synaptic plasticity and memory storage. In the forebrain, the anchoring protein gravin recruits a signaling complex containing PKA, PKC, calmodulin, and PDE4D (phosphodiesterase 4D) to the $\beta 2$-adrenergic receptor. Here, we show that mice lacking the $\alpha$-isoform of gravin have deficits in PKA-dependent long-lasting forms of hippocampal synaptic plasticity including $\beta 2$-adrenergic receptor-mediated plasticity, and selective impairments of long-term memory storage. Furthermore, both hippocampal $\beta 2$-adrenergic receptor phosphorylation by PKA, and learning-induced activation of ERK in the CA1 region of the hippocampus are attenuated in mice lacking gravin- $\alpha$. We conclude that gravin compartmentalizes a significant pool of PKA that regulates learning-induced $\beta 2$-adrenergic receptor signaling and ERK activation in the hippocampus in vivo, thereby organizing molecular interactions between glutamatergic and noradrenergic signaling pathways for long-lasting synaptic plasticity, and memory storage.
\end{abstract}

\section{Introduction}

A-kinase anchoring proteins (AKAPs) are a family of functionally distinct but structurally related proteins that localize protein kinase A (PKA) and other signaling molecules to specific subcellular compartments (e.g., synapses) (Welch et al., 2010). Genetic and pharmacological inhibition of PKA anchoring impairs hippocampal synaptic plasticity and memory (Moita et al., 2002; Snyder et al., 2005; Huang et al., 2006; Nie et al., 2007; Nijholt et al., 2007), but the specific AKAPs involved in these PKA-

Received July 28, 2012; revised Oct. 2, 2012; accepted 0ct. 21, 2012.

Author contributions: R.H., G.S.B., J.D.S., and T.A. designed research; R.H., D.A.C., A.J.P., T.H., T.N., J.P.D., L.A.G., Q.G., and V.L. performed research; I.H.G. contributed unpublished reagents/analytic tools; R.H., D.A.C., A.J.P., T.H., and T.N. analyzed data; R.H. wrote the paper.

This work was supported by The Netherlands Organization for Scientific Research NW0-Rubicon Grant 825.07.029 (R.H.), the Kwanjeong Educational Foundation (A.J.P.), the Human Frontiers Science Program (T.A.), the National Institutes of Health (T.A.), National Institute on Alcohol Abuse and Alcoholism Grant R01 AA18060 (T.A.), and National Institute of General Medical Sciences Grant GM-48231 (J.D.S.). G.S.B. and J.P.D. were supported by Medical Research Council (United Kingdom) Grant G0600765 and Fondation Leducq Grant 06CVD02. We thank Dr. Jacqueline Barra for providing us with the gravin GT mouse line. We thank Drs. Seth Grant, Marcelo Coba, and members of the Abel Laboratory for helpful comments on a previous version of this manuscript, and Dr. Carlos Sindreu for technical advice.

The authors declare no competing financial interests.

${ }^{*}$ D.A.C., A.J.P., T.H., and T.N. contributed equally to this work.

Correspondence should be addressed to either Robbert Havekes or Ted Abel, Department of Biology, University of Pennsylvania, Philadelphia, PA 19104-6018, E-mail: havekesr@sas.upenn.edu or abele@sas.upenn.edu.

T. Nie's present address: Department of Pediatrics, Emory University, Veteran Affairs Medical Center, 1670 Clairmont Road, Atlanta, GA 30033.

DOI:10.1523/JNEUROSCI.3612-12.2012

Copyright $\odot 2012$ the authors $\quad 0270-6474 / 12 / 3218137-13 \$ 15.00 / 0$ dependent processes, and the details of their exact functions, have not been clearly identified.

Genetic analysis of AKAP complexes involved in mediating synaptic plasticity and memory has focused on the AKAP5 gene (also known as AKAP150 in mice), because it is associated with AMPA and NMDA receptors (Colledge et al., 2000). Loss of AKAP150 disrupts hippocampal LTD, alters AMPA receptormediated synaptic transmission, and results in memory deficits in the Morris water maze (Tunquist et al., 2008). Surprisingly, a genetic mutation leading to a selective disruption of PKAAKAP150 binding disrupts long-term potentiation (LTP) in adult mice (Lu et al., 2007) but does not induce a memory deficit in the Morris water maze (Weisenhaus et al., 2010). These findings suggest that either (1) other AKAP150 binding partners or (2) distinct PKA-AKAP complexes contribute to hippocampal synaptic plasticity and memory formation.

$\beta$-Adrenergic receptors ( $\beta$-ARs) play a critical role in emotional arousal, metaplasticity, and long-term memory formation (McGaugh, 2000; Gibbs and Summers, 2002) through activation of the cAMP signaling pathway (O'Dell et al., 2010). Occupancy of $\beta 2$-adrenergic receptors ( $\beta 2$-ARs) by their ligand noradrenaline (norepinephrine) leads to the coupling of the receptor with guanine nucleotide regulatory proteins $(\mathrm{G} \alpha \mathrm{s})$, cAMP production, and the association of PKA with the $\beta 2$-AR (Shih et al., 1999; Lin et al., 2000). Phosphorylation of the $\beta 2$-AR by PKA switches the coupling from $\mathrm{G} \alpha$ s to inhibitory guanine nucleotide regulatory protein $(\mathrm{G} \alpha \mathrm{i})$, thereby activating $\mathrm{G} \alpha \mathrm{i}$-linked signaling path- 
ways implicated in memory such as the extracellular-regulated kinase 1/2 (ERK1/2) pathway (Daaka et al., 1997; Atkins et al., 1998; Baillie et al., 2003; Sindreu et al., 2007). One anchoring protein that recruits PKA to the $\beta 2$-AR upon receptor occupancy is the anchoring protein gravin (Tao et al., 2003). Gravin, also known as Src-suppressed C kinase substrate (SSeCKS), AKAP12, and AKAP250 (Lin et al., 1996; Willoughby et al., 2006), is a multivalent scaffolding protein that binds PKA and PKC (Nauert et al., 1997), sequesters calmodulin (Lin and Gelman, 2002), and targets phosphodiesterase 4D (PDE4D) to the plasma membrane (Willoughby et al., 2006).

Although gravin modulates $\beta 2$-AR signaling complexes in vitro, it remains to be determined whether gravin plays a role in hippocampal synaptic plasticity and memory formation in vivo. We answered this important question by using a gene-trap mouse model (referred to as gravin GT mice) that lacks the $\alpha$-isoform of gravin (Camus et al., 2001) and defined the role of gravin- $\alpha$ in $\beta 2$-AR-mediated signaling events important for learninginduced ERK1/2 activation, long-lasting forms of synaptic plasticity and long-term memory.

\section{Materials and Methods}

\section{Animals}

The gravin GT mice, also referred to as SSeCKS mutants (Camus et al., 2001), were a gift from Dr. Jacqueline Barra (Institut Pasteur, Paris, France) and backcrossed to a C57BL/6J background for $>10$ generations. Male and female 3- to 5-month-old gravin GT mice and wild-type littermates had ad libitum access to food and water and were maintained on a $12 \mathrm{~h}$ light/dark cycle with behavioral testing occurring during the light phase. Experimentally naive mice were used for each experiment, individually housed for 1 week, and handled for $2 \mathrm{~min}$ for 3 consecutive days before the behavioral experiments. All experiments were conducted according to National Institutes of Health guidelines for animal care and use and were approved by the Institutional Animal Care and Use Committee of the University of Pennsylvania.

\section{Genotyping}

Tail DNA was used to genotype mice by PCR with three primers, two in the intron sequences of gravin between exon $1 \mathrm{~A} 2$ and $1 \mathrm{~B}$ (AGGGCTACCCAGAGAGATCC and GCTGTTTGGGAGCAGAAAAG) and one at the 3' end of LacZ gene (GCAGAGCGAGGTATGTAGGC). The cycling parameters for PCR genotyping were $94^{\circ} \mathrm{C}, 1 \mathrm{~min} ; 60^{\circ} \mathrm{C}, 1 \mathrm{~min}$; and $72^{\circ} \mathrm{C}$, $1 \mathrm{~min}$ for 40 cycles. PCR products consisted of one $562 \mathrm{bp}$ band for homozygous GT mice, one 730 bp band for wild-type mice, or both 562 and $730 \mathrm{bp}$ bands for heterozygous mice.

\section{In situ hybridization}

The sequence of the antisense oligonucleotide against gravin is CCGACAATGCCTCCAGGTCACCGACCTGGTC and designed by SigmaGenosys. A sense probe control was accordingly designed. The hybridization was performed on $20 \mu \mathrm{m}$ sections of the brain of 2-monthold C57BL/6J wild-type mice as previously described (Abel et al., 1997).

\section{Immunohistochemistry}

Transcardial perfusions and immunohistochemical stainings were conducted as previously described (Havekes et al., 2006, 2007; Vecsey et al., 2009). Sections incubated with either rabbit Map2 antibody (Millipore; AB5622; 1:1000) or mouse gravin antibody (Sigma-Aldrich; JP74; 1:200) followed by incubation with the appropriate Alexa Fluor 488 antibodies (Invitrogen). Imaging was conducted on a Leica confocal microscope. In case of the phospho-ERK1/2 staining, we used rabbit anti-phosphoERK1/2 (Cell Signaling; AB9101; 1:100), and phosphatase inhibitors were included in the fixative and all buffers (Sindreu et al., 2007). After incubation with primary antibody, sections were washed in PBS for $1 \mathrm{~h}$ followed by incubation with biotinylated-conjugated goat anti-rabbit IgG antibody (Jackson ImmunoResearch; 1:500) for $3 \mathrm{~h}$. After washing in PBS for $1 \mathrm{~h}$, sections were incubated with the avidin-biotin horseradish peroxidase complex (ABC kit; Vector Laboratories; 1:500). After $3 \mathrm{~h}$ of washing in PBS, sections were processed with diaminobenzidine $(0.02 \%)$ with $100 \mu \mathrm{l}$ of $0.1 \% \mathrm{H}_{2} \mathrm{O}_{2}$ as a reaction initiator. Processing was visually monitored and stopped by rinsing with PBS. Cell counts and optical density measurements were conducted as described previously (Van der Borght et al., 2007; Hagewoud et al., 2011) using a Micromaster light miscroscope.

\section{RNA isolation and cDNA synthesis}

Hippocampi were dissected and stored at $-80^{\circ} \mathrm{C}$ in $500 \mu \mathrm{l}$ of RNAlater (Ambion). RNA extraction and cDNA synthesis using the RETROscript (Ambion) kit were conducted as described previously (Vecsey et al., 2009).

\section{Quantitative real-time reverse transcription- $P C R$}

The reactions were assembled in 96-well optical reaction plates (Applied Biosystems) and covered with optical adhesive covers (Applied Biosystems). cDNA was diluted to $2 \mathrm{ng} / \mu \mathrm{l}$ with DEPC-treated $\mathrm{H}_{2} \mathrm{O}$ and added in a quantity of $11.4 \mu \mathrm{l}$ per well. Each well also contained $1 \mu \mathrm{l}$ of $5 \mu \mathrm{M}$ primers and $12.4 \mu \mathrm{l}$ of Quantitect SYBR Green PCR master mix (QIAGEN). Five primer sets were used to assess the relative expression of gravin mRNA in the hippocampus. The gravin- $\alpha 1 a$ and gravin- $\alpha 1 b$ primer sets probe for transcripts spanning exon 1A1 to exon 2: primers gravin- $\alpha 1 a$ (forward, 5 '-GCTCAGTGGCCATGGGCCCGCAG; reverse, $5^{\prime}$-TGCCATTTCTTTAGCTCGGTCTTTTTC), gravin- $\alpha 1 b$ (forward, 5'-GCTGGAGATCCCGCTGAC; reverse, 5'-GTTTCCTCCTGCTCGT CCTT). Gravin- $\alpha 2$ probes for the $\alpha$-isoform of gravin spanning exon $1 \mathrm{~A} 2$ to exon 2 (forward, $5^{\prime}$-AAGAATGGTCAGCTGTCTGC; reverse, 5'-TGACAGTGAGTAGCTGGACG). These three primer sets all probe for the presence of the gravin- $\alpha$ transcript. The gravin- $\beta$ primer and $L a c Z$ primer set probe for the $\beta$ transcript (forward, 5'-AGGAGAAGGAGA CTTCCTGC; reverse, $5^{\prime}$-TGACAGTGAGTAGCTGGACG), and gravinlac $Z$ transcript (forward, 5'-TGGGCAAGAGGAAGAAGTCA; reverse, 5'-ATGTGAGCGAGTAACAACCCGTCGGATTCT), respectively. The reaction was run in the Applied Biosystems ABI Prism 7000 and began with a $2 \mathrm{~min}$ incubation at $50^{\circ} \mathrm{C}$ followed by $15 \mathrm{~min}$ at $90^{\circ} \mathrm{C}$. Afterward, the reaction proceeded through 40 cycles of the following: (1) $95^{\circ} \mathrm{C}$ for $15 \mathrm{~s}$; (2) $56^{\circ} \mathrm{C}$ for $30 \mathrm{~s}$; and (3) $72^{\circ} \mathrm{C}$ for $30 \mathrm{~s}$. Data were collected at stage 3 of each cycle and the products were examined with a dissociation curve consisting of two sets of sequential incubations at $95^{\circ} \mathrm{C}$ for $15 \mathrm{~s}$ and $60^{\circ} \mathrm{C}$ for $1 \mathrm{~min}$. Data were normalized against actin G (actg), hypoxanthine phosphoribosyltransferase ( $h p r t)$, and Tubulin $(t u b 4 a)$. Relative expression levels were calculated according to the procedure in the Applied Biosystems manual using the standard curve method.

\section{Electrophysiology}

Electrophysiological recordings were performed as described previously (Vecsey et al., 2009). LTP was induced using the following protocols: spaced four-train (four $1 \mathrm{~s} 100 \mathrm{~Hz}$ trains delivered 5 min apart), massed four-train (four $1 \mathrm{~s} 100 \mathrm{~Hz}$ trains delivered $5 \mathrm{~s}$ apart), theta-burst (bursts of four $100 \mathrm{~Hz}$ pulses delivered for a total of $3 \mathrm{~s}$ at $5 \mathrm{~Hz}$ ), and one-train stimulus (one $1 \mathrm{~s} 100$ $\mathrm{Hz}$ train of pulses). LTP was also induced by pairing a $5 \mathrm{~Hz}, 3$ min stimulation with application of the $1 \mu \mathrm{M} \beta$-adrenergic agonist isoproterenol (ISO) for $25 \mathrm{~min}$. The electrical stimulation was given $15 \mathrm{~min}$ into ISO treatment. ISO (Sigma-Aldrich) was prepared daily as a $10 \mathrm{~mm}$ stock solution in Milli-Q water. Synthesis of stearated Ht31 (stHt31) (St-N-DLIEEAASRIVDAVIEQV KAAGAY-C) and pseudo-Ht31 peptide (stHt31P) (St-N-DLIEEAASRPVD AVPEQVKAAGAY-C) (Carr et al., 1992; Vijayaraghavan et al., 1997; Huang et al., 2006) was conducted by Quality Controlled Biochemicals. Lyophilized powder was resuspended at a stock concentration of $10 \mathrm{~mm}$ in $50 \mathrm{~mm}$ Tris$\mathrm{HCl}, \mathrm{pH} 7.0$, and $0.05 \%$ DMSO and used at $10 \mu \mathrm{M}$ final concentration in aCSF. Forskolin was dissolved in $100 \%$ ethanol to make $50 \mathrm{~mm}$ stock solution and used at $50 \mu \mathrm{M}$ final concentration in aCSF. The $\beta 2$-AR antagonist 3-(isopropylamino)-1-[(7-methyl-4-indanyl)oxy]butan-2-ol (ICI 118551) (Sigma-Aldrich) was dissolved in $\mathrm{H}_{2} \mathrm{O}$ at a stock concentration of $100 \mu \mathrm{M}$ and used at a $100 \mathrm{~nm}$ final concentration in aCSF.

Tissue lyses, Western blot analyses, and PKA activity assays Proteins were separated by SDS-PAGE and transferred to PVDF membrane as described previously (Vecsey et al., 2009). The following primary antibodies were used: ERK1/2 (Cell Signaling; AB9102; 1:1000), 
pERK1/2 (Cell Signaling; AB9101; 1:1000), $\beta 2$-AR (Santa Cruz; sc-569; 1:1000), p $\beta 2$-AR (Santa Cruz; sc-16718; 1:200), pGluA1 Ser845 (Millipore; AB5849; 1:1000), and GluA1 (Millipore; MAB2263; 1:50,000). After incubation with the primary antibodies, membranes were incubated with HRP-conjugated secondary antibodies for $1 \mathrm{~h}$ at room temperature (Santa Cruz; mouse secondary antibody, 1:1000; Santa Cruz; rabbit secondary antibody, 1:5000). PKA activity measurements were conducted on hippocampal lysates using a PKA activity ELISA kit according to the manufacturer's instructions (Arbor Assays; catalog \#K027-H1).

\section{Neuronal cultures}

Primary neuronal cultures were prepared from hippocampi of embryonic day 17.5 mice, as described previously (Banker and Cowan, 1977). Dissociated neurons were plated onto poly-L-lysine-treated glass coverslips at a density of $25-50$ cells $/ \mathrm{mm}^{2}$ and cocultured over a monolayer of astrocytes. Cells were maintained in Neurobasal medium (Invitrogen) supplemented with B27 and Glutamax. After incubation with the following primary antibodies: anti-PKA RII- $\alpha$ polyclonal (Santa Cruz; PKA RII- $\alpha$ sc-909; 1:200) and anti-gravin monoclonal (Sigma-Aldrich; G3795; 1:200), neurons were incubated with the appropriate Alexa Fluor-conjugated secondary antibodies for $2 \mathrm{~h}$ at room temperature. Neurons were imaged with a Zeiss confocal microscope.

\section{Coimmunoprecipitation and RII overlays}

Hippocampi were pulverized under liquid nitrogen and homogenized in HSE lysis buffer (20 mм HEPES, pH 7.2, $150 \mathrm{~mm} \mathrm{NaCl}, 5$ mм EDTA, 1\% Triton X-100). Extracts were rocked for $1 \mathrm{~h}$ at $4^{\circ} \mathrm{C}$ and subsequently centrifuged at $19,400 \times \mathrm{g}$ for $20 \mathrm{~min}$ at $4^{\circ} \mathrm{C}$. Equal amounts of protein were subjected to immunoprecipitation with $5 \mu \mathrm{g}$ of anti-gravin (SigmaAldrich; G3795) by rocking overnight at $4^{\circ} \mathrm{C}$. Lysates were recentrifuged at $19,400 \times g$, and protein A and protein G beads (1:1 slurry) were added for $1 \mathrm{~h}$. Beads were collected by centrifugation and washed four times in HSE lysis buffer. Bound proteins were eluted with $2 \times$ LDS sample buffer, separated on $4-12 \%$ SDS-PAGE gels (Bio-Rad) and transferred to nitrocellulose for immunoblotting. The following antibodies were used: anti-gravin monoclonal antibody (Sigma-Aldrich; G3795; 1:1000), anti-GAPDH (Sigma-Aldrich; G8795; 1:1000), anti-MAP2 (Sigma-Aldrich; M9942; 1:1000), anti- $\beta$-galactosidase (Promega; Z378A; 1:200), anti-pERK1/2 (Cell Signaling; AB9101; 1:1000), ERK1/2 (Cell Signaling; AB9102; 1:1000), and antiAKAP150 (V088; 1:1000). Western blot data were collected using an Alpha Innotech MultiImage III with FluoroChemQ software. For the RII overlays, nitrocellulose membranes were blocked and then incubated with digoxigenin-labeled PKA RII overnight at $4^{\circ} \mathrm{C}$. Binding was detected using HRP-labeled anti-digoxigenin (Abcam; ab62120).

\section{Behavioral testing}

Morris water maze. Training and testing in the hidden platform version of the water maze were performed as described previously (Abel et al., 1997). Naive mice were used in the visible platform experiment in the Morris water maze.

Object-place recognition task and novel object recognition task. Both tasks were performed as described previously (Oliveira et al., 2010).

Fear conditioning. Experiments were performed in standard conditioning chambers (San Diego Instruments) as described previously (Abel et al., 1997). Freezing behavior (defined as complete immobility except for breathing) was scored during the training and retention sessions.

Rotarod. Mice were placed on a 3-cm-diameter rotating rod elevated $16 \mathrm{~cm}$ and allowed to walk on it for $30 \mathrm{~s}$ at $4 \mathrm{rpm}$. Twenty-four hours later, mice were placed on the rotating rod again for no more than $5 \mathrm{~min}$ as it accelerated from 4 to $40 \mathrm{rpm}$. The time at which each mouse fell was recorded, and each was placed on the rod twice more at $1 \mathrm{~h}$ intervals. This procedure was repeated for 3 consecutive testing days.

Exploratory and locomotor activity. Baseline exploratory and locomotor activities were measured in a gray rectangular box $(60 \times 50 \times 26 \mathrm{~cm})$ built of polyvinyl chloride plastic. Mice were placed in the open field for $10 \mathrm{~min}$. The time spent in peripheral and central areas and the velocity of travel were recorded using a video tracking system (Clever Systems).

Zero maze. Anxiety-related behavior was tested in the elevated zero maze as described previously (Tretter et al., 2009).

\section{Data analysis}

Data analysis was performed using SPSS. Behavioral data were analyzed using two-way ANOVAs (in some cases with repeated measures as the within-subject variable) or Student's $t$ tests. Tukey-Kramer tests were used for post hoc analyses when necessary. Biochemical data were analyzed using independent $t$ tests. Electrophysiological data were analyzed using nonparametric tests (Nie et al., 2007). The initial slope of the fEPSP at each time point was analyzed. For comparisons of the average slope over the last $20 \mathrm{~min}$ of the recording, the Mann-Whitney $U$ test was used. Differences were considered statistically significant when $p<0.05$. Data are plotted as mean \pm SEM.

\section{Results \\ Hippocampal gravin- $\alpha$ but not gravin- $\beta$ is lost due to gene trap insertion in gravin GT mice}

In rodents, three gravin isoforms $(\alpha, \beta$, and $\gamma)$ are transcribed from a single gene locus ( gravin). The transcription of each isoform is controlled by different promoters, yielding distinct mRNA transcripts and proteins that differ at their $\mathrm{N}$ termini (Streb et al., 2004). The $\alpha$ and $\beta$ isoforms are expressed widely throughout the body, but the $\gamma$ isoform is only found in the testis (Camus et al., 2001). The unique N-terminal myristoylation motif in gravin- $\alpha$ facilitates enrichment at the plasma membrane (Lin et al., 1996; Streb et al., 2004), where it can interact with G-protein-coupled receptors such as the $\beta 2$-AR (Shih et al., 1999). Gravin mRNA expression is observed in mouse forebrain regions (Fig. $1 A, B$ ), including the three major hippocampal regions [CA1, CA3, and dentate gyrus (DG)]. Moderate labeling was observed in the granule cells of the cerebellum (Fig. 1C). Immunohistochemical analyses confirmed the mRNA studies showing protein expression of gravin in the dorsal hippocampus (Fig. 1D). Higher magnification images reveal prominent gravin expression in the perinuclear region of CA1 and CA3 pyramidal cells (Fig. 1 E, F) and dentate gyrus granular cells (Fig. $1 G$ ). Signals for gravin and the RII- $\alpha$ isoform of PKA overlap in cultured mouse hippocampal neurons (Fig. $1 H-J$ ), consistent with the role of gravin as an A-kinase anchoring protein.

To examine the role of this anchoring protein in hippocampal function, we used gravin GT mice because these animals give us the opportunity to exclusively assess the function of the myristoylated $\alpha$-isoform of gravin. The gravin GT mouse line was generated by a gene trap insertion of the $L a c Z$ reporter into the genomic sequence encoding gravin between exon $1 \mathrm{~A} 2$ and $1 \mathrm{~B}$ (Fig. $1 K$ ) (Camus et al., 2001). A significant decrease in gravin- $\alpha$ mRNA levels was detected using three distinct primer sets: gravin- $\alpha 1 a$ (both groups, $n=6$; Student's $t$ test, $p=0.009$; Fig. $1 L$ ), gravin- $\alpha 1 b$ (both groups, $n=3$; Student's $t$ test, $p=0.039$; Fig. $1 L$ ), and gravin- $\alpha 2$ (both groups, $n=6$; Student's $t$ test, $p=$ 0.013 ; Fig. $1 L$ ), all representing the gravin- $\alpha$ transcript. Gravin GT mice exhibit normal expression of the gravin- $\beta$ isoform (both groups, $n=6$; Student's $t$ test, $p=0.444$; Fig. $1 L$ ), suggesting that loss of the gravin- $\alpha$ transcript does not result in compensatory upregulation of the gravin- $\beta$ transcript in the hippocampus.

Biochemical approaches were used to further characterize gravin GT mice. Western blot analyses indicated that the majority of full-length gravin was lost in these animals, with the remaining fraction representing the $\beta$-isoform of gravin (Fig. $1 M$, left panel). Gravin GT mice expressed a truncated form of gravin of $\sim 150 \mathrm{kDa}$ (Fig. 1M, left panel) that consisted of an N-terminal portion of the anchoring protein fused to lacZ (Fig. $1 \mathrm{M}$, middle panel). The RII-overlay assay confirmed that this truncated fusion protein did not bind PKA (Fig. $1 \mathrm{M}$, right panel). Because gravin and another anchoring protein, AKAP150, both coordinate $\beta 2$-AR-mediated signaling (Tao and Malbon, 2008), we 

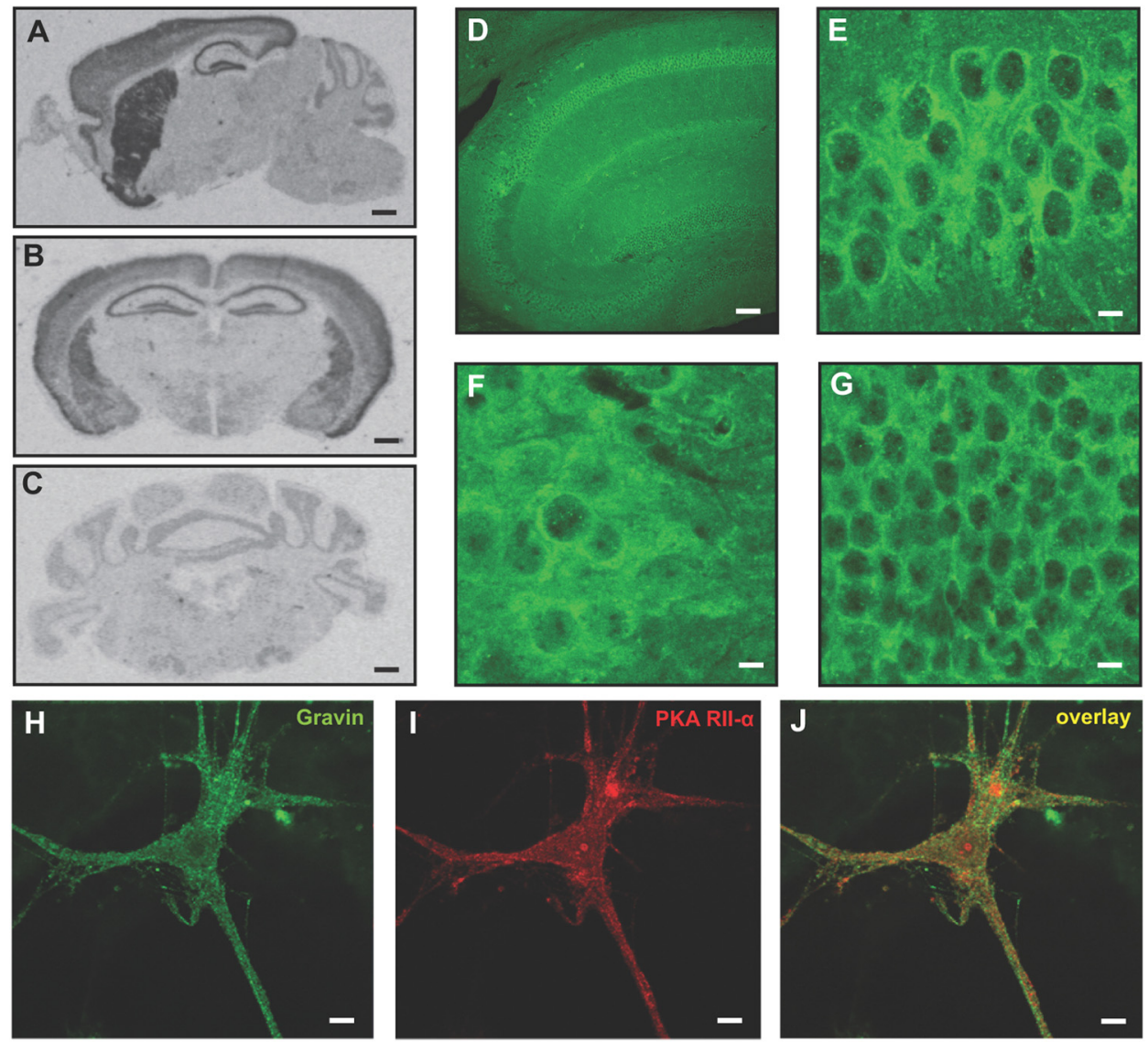

K
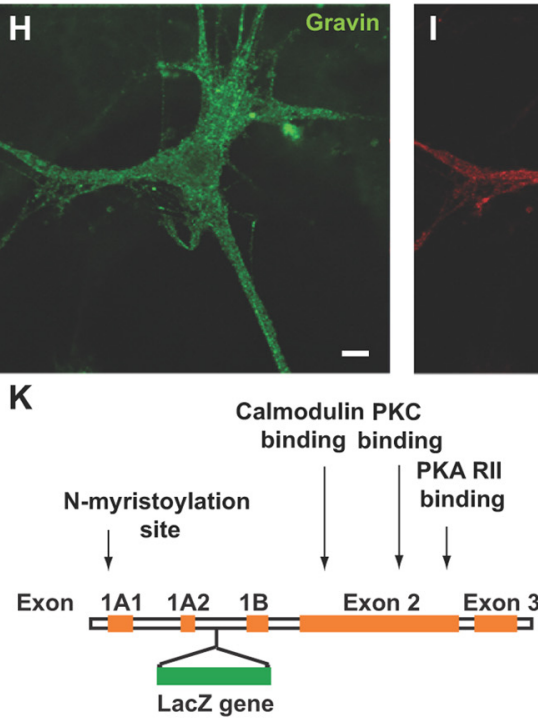

M

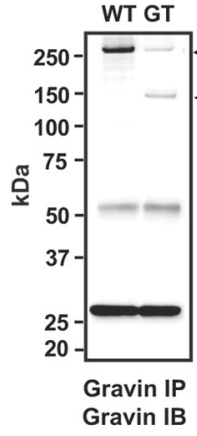

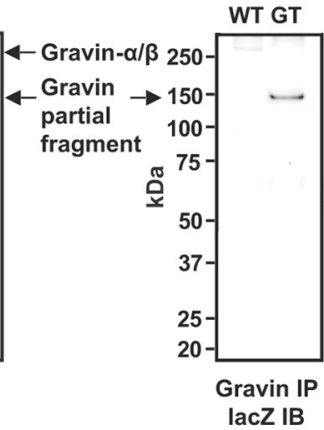

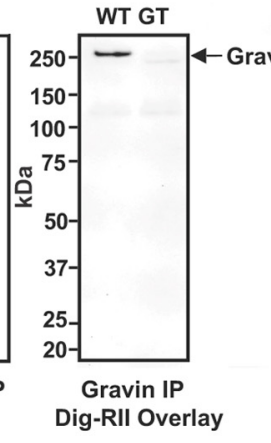

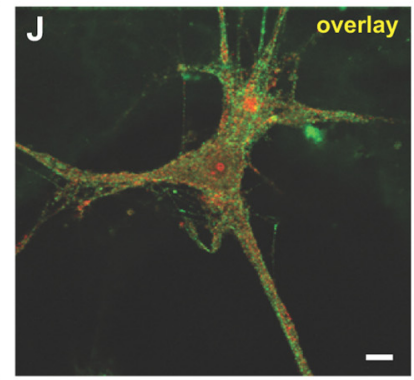

$\mathbf{L}$

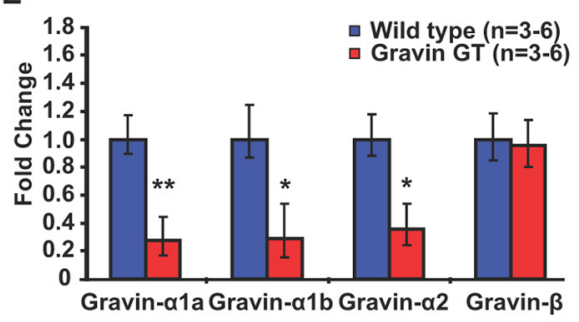

$\mathbf{N}$
AKAP150

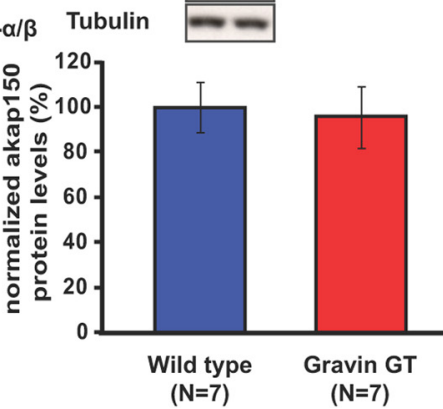

Havekes et al

Figure 1. Expression of the $\alpha$-isoform of gravin is reduced in gravin GT mice. A, A sagittal brain section showing gravin mRNA expression in the hippocampus, striatum, cortex, and olfactory bulb. $\boldsymbol{B}, A$ coronal brain section showing gravin mRNA in the hippocampus, cortex, amygdala, and striatum. $\boldsymbol{C}$, Gravin mRNA is expressed at lower levels in the granular cell layer of the cerebellum. Scale bar, $800 \mu \mathrm{m}$. D. Gravin protein expression in the dorsal hippocampus. Scale bar, $200 \mu \mathrm{m}$. Higher magnification images of gravin protein expression in CA1 pyramidal cells (E), CA3 pyramidal cells $(\boldsymbol{F})$, and granular cells of the dentate gyrus $(\boldsymbol{G})$. Scale bar, $20 \mu \mathrm{m}$. Gravin $(\boldsymbol{H})$ and PKA RII- $\alpha(\boldsymbol{I})$ are strongly colocalized $(\boldsymbol{J})$ in cultured mouse hippocampal neurons. Scale bar, $20 \mu \mathrm{m}$. $\boldsymbol{K}, \mathrm{A}$ schematic representation of the gravin gene. The gravin- $\alpha$ transcript consists of exons $1 A 1,1 A 2,2$, and 3 . The gravin- $\beta$ transcript consists of exons $1 B, 2$, and 3 . The gravin GT mice carry a LacZ insertion in the intron between exons $1 \mathrm{~A} 2$ and 1B (Camus et al., 2001). This insertion site precedes the promoter region for the $\beta$ transcript (Camus et al., 2001). $L$, Quantitative PCR experiments reveal reduced expression levels of gravin- $\alpha$ in gravin GT mice. mRNA levels for gravin- $\alpha 1 a$ (Student's $t$ test, $n=6, p=0.009$ ), gravin- $\alpha 1 b$ (Student's $t$ test, $n=3, p=0.039$ ), and gravin- $\alpha 2$ (Student's $t$ test, $n=6, p=0.014$ ). Gravin- $\beta$ expression was not affected in gravin GT mice (Student's t test, $n=6, p=0.444$ ). $M$, Gravin GT mice express a truncated form of gravin- $\alpha$ of $\sim 150 \mathrm{kDa}$ (left panel), which contains LacZ (middle panel) but lacks an RIl binding site (right panel). $\boldsymbol{N}$, Hippocampal AKAP150 protein levels are not altered in gravin GT mice ( $n=7$ for both groups; Student's $t$ tests, $p=$ 0.79). ${ }^{*} p<0.05 ;{ }^{* *} p<0.01$. Error bars indicate SEM. 
A
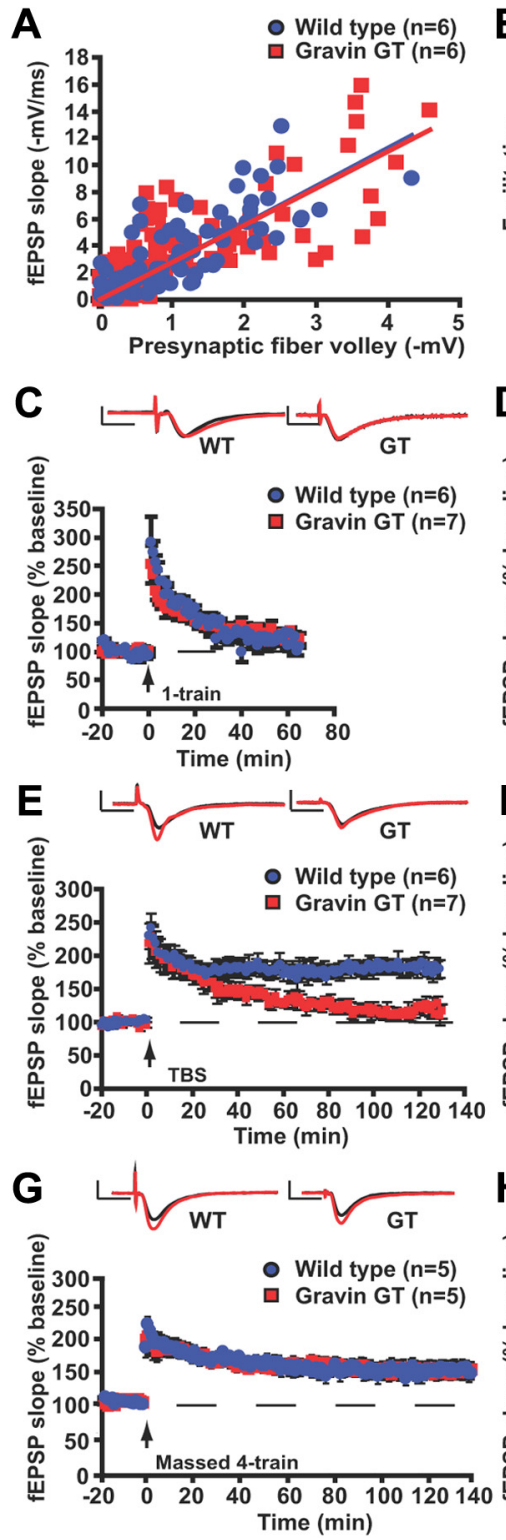

Figure 2. Long-lasting hippocampal LTP is impaired in gravin GT mice. $\boldsymbol{A}$, Input- output curves relating the amplitude of the presynaptic fiber volley to the initial slope of the corresponding fEPSP at various stimulus intensities was not altered in slices from gravin GT mice (one-way ANOVA, $F_{(1,10)}=0.128, p=0.727$ ). $B$, Paired-pulse facilitation, a short-term form of synaptic plasticity, was not changed in slices from gravin GT mice (two-way repeated-measures ANOVA, $F_{(4,44)}=0.415, p=0.797$ ). C, One-train LTP was unaltered in hippocampal slices from gravin GT mice (Kruskal-Wallis ANOVA, $p>0.05$ ). D, Spaced four-train LTP is impaired in slices from gravin GT mice (Kruskal-Wallis ANOVA, $p<0.05$ ). $\boldsymbol{E}$, A long-lasting form of LTP induced by theta-burst stimulation (15 bursts) was impaired in slices from gravin GT mice (Kruskal-Wallis ANOVA, $p<0.05$ ). F, Bath application with the $\beta 2$-AR antagonist ICI 118551 (100 nM) impairs a long-lasting form of LTP induced by theta-burst stimulation (15 bursts) (Kruskal-Wallis ANOVA, $p<0.05)$. G, Massed four-train LTP, a PKA-independent form of long-lasting LTP was not impaired in slices from gravin GT mice (Kruskal-Wallis ANOVA, $p>0.05$ ). $\boldsymbol{H}$, Forskolin-mediated synaptic potentiation was not impaired in slices from gravin GT mice (Kruskal-Wallis ANOVA, $p>0.05$ ). In all sample sweeps, black traces indicate baseline, and red traces were acquired at $1 \mathrm{~h}$ after tetanus (for $\boldsymbol{C}$ ) or $\sim 2 \mathrm{~h}$ after stimulation (for $\boldsymbol{D}-\boldsymbol{H}$ ). Calibration: $2 \mathrm{mV}, 10 \mathrm{~ms}$. Error bars indicate SEM.
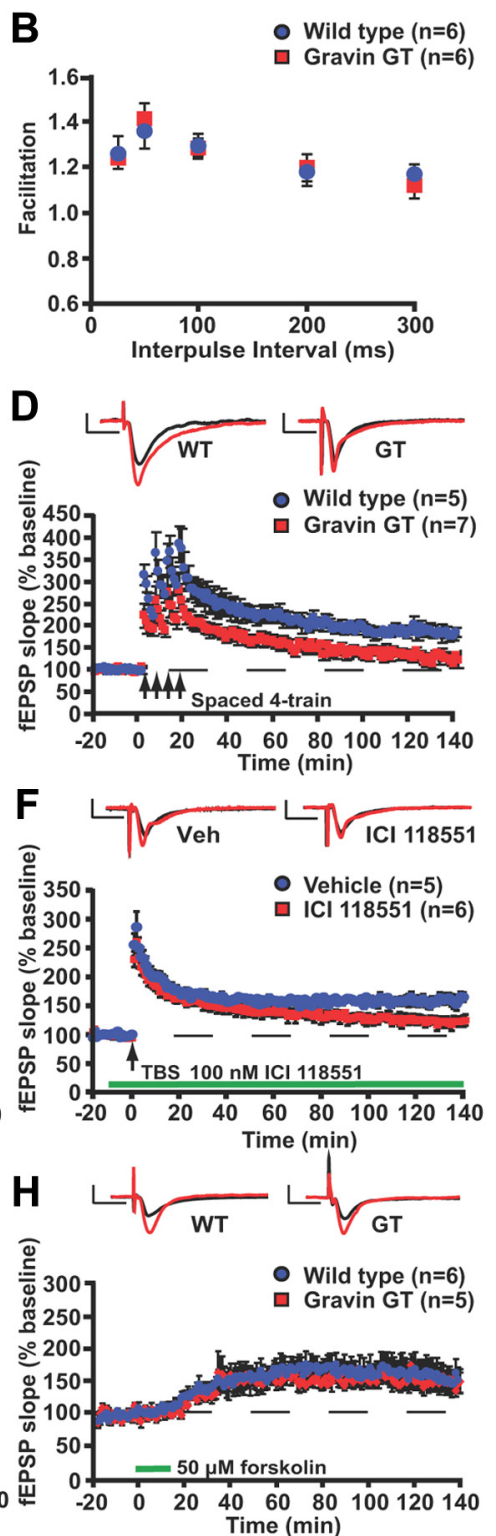
Schaffer collateral-CA1 synapses was impaired in slices from gravin GT mice (WT, $n=6$; GT, $n=7$; Kruskal-Wallis ANOVA, $p<0.05$; Fig. $2 E$ ). The mean fEPSP slope over the last $20 \mathrm{~min}$ of the recording was significantly reduced in gravin GT mice (WT, $183.1 \pm 11.6 \%$; GT, $114.1 \pm 7.7 \%$; Mann-Whitney $U$ test, $p=$ $0.004)$. To determine whether theta-burst LTP requires $\beta 2$-ARs, we repeated the experiment in wild-type mice with bath application of the $\beta 2$-AR antagonist ICI 118551 (100 nM). Theta-burst LTP at Schaffer collateral-CA1 synapses was impaired in slices from wild-type slices treated with the $\beta 2$-AR antagonist (WT, $n=5$; GT, $n=6$; Kruskal-Wallis ANOVA, $p<0.05$; Fig. $2 F$ ). The mean fEPSP slope over the last $20 \mathrm{~min}$ of the recording was significantly reduced under conditions of the $\beta 2$-AR blocker (vehicle, $156.3 \pm 10.1 \%$; ICI 118551, $119.3 \pm 7.1 \%$; Mann-Whitney $U$ test, $p=0.007)$. Together, these data indicate that loss of gravin- $\alpha$ impairs long-lasting forms of synaptic plasticity.

LTP induced by four high-frequency trains of stimuli applied at $5 \mathrm{~s}$ intervals (massed four-train LTP) produces a form of longlasting LTP that does not require cAMP/PKA signaling (Woo et al., 2003). Therefore, we anticipated that this form of LTP would not be impaired by loss of gravin- $\alpha$. As expected, massed fourtrain LTP was not affected by loss of gravin- $\alpha$ (WT, $n=5$; GT, $n=5$; Kruskal-Wallis ANOVA, $p>0.05$; Fig. $2 G$ ). Together, these data indicate that loss of gravin- $\alpha$ impairs long-lasting LTP that requires PKA anchoring without affecting PKA-independent forms of LTP.

We next wanted to establish whether loss of gravin- $\alpha$ impairs a form of synaptic potentiation that is induced by forskolin, a pharmacological activator of adenylyl cyclase (Huang and Kandel, 1998). The synaptic potentiation following forskolin treatment was similar in wild-type littermates and gravin GT mice (WT, $n=6$; GT, $n=5$; Kruskal-Wallis ANOVA, $p>0.05$; Fig. $2 \mathrm{H}$ ). These findings suggest that cell-wide elevation of cAMP to supraphysiological levels overcomes the mislocalization of PKA caused by the deletion of gravin- $\alpha$ in the mutant mice.

\section{$\beta 2$-Adrenergic receptor-mediated synaptic plasticity is impaired in gravin GT mice}

Gravin-coordinated signaling complexes have been proposed to modulate $\beta 2$-AR function (Tao and Malbon, 2008), but this has not been tested physiologically. Occupancy of $\beta$-ARs, when paired with distinct patterns of excitatory synaptic stimulation, can enhance hippocampal LTP (Winder et al., 1999; Gelinas et al., 2008; Qian et al., 2012). We first determined whether bath application of the $\beta$-AR agonist ISO alone induced changes in synaptic strength. Twenty-five minutes of ISO treatment did not induce any synaptic potentiation in hippocampal slices from either wildtype or gravin GT mice (data not shown). Next, we examined whether an ISO-induced form of plasticity is attenuated in the gravin GT mice. Transient low-frequency stimulation (LFS) (5 $\mathrm{Hz}$ for $3 \mathrm{~min}$ ) does not cause persistent changes in synaptic strength (Qian et al., 2012). However, pairing ISO with LFS establishes long-lasting LTP (Winder et al., 1999; Gelinas et al., 2008) via the activation of PKA (Gelinas et al., 2008) and ERK1/2 (Winder et al., 1999). A recent study showed that this form of plasticity specifically requires $\beta 2-\mathrm{AR}$ activation (Qian et al., 2012). Synaptic plasticity at Schaffer collateral-CA1 synapses induced by pairing $1 \mu \mathrm{M}$ ISO with LFS ( $5 \mathrm{~Hz}$ for $3 \mathrm{~min}$ ) was impaired in slices from gravin GT mice (both groups, $n=4$; Kruskal-Wallis ANOVA, $p<0.05$; Fig. $3 A$ ). The mean fEPSP slope over the last $20 \mathrm{~min}$ of the recording was significantly reduced in gravin GT mice relative to WT mice (WT, $226.2 \pm$ $17.1 \%$; GT, $135.3 \pm 7.9 \%$; Mann-Whitney $U$ test, $p=0.003$ ).
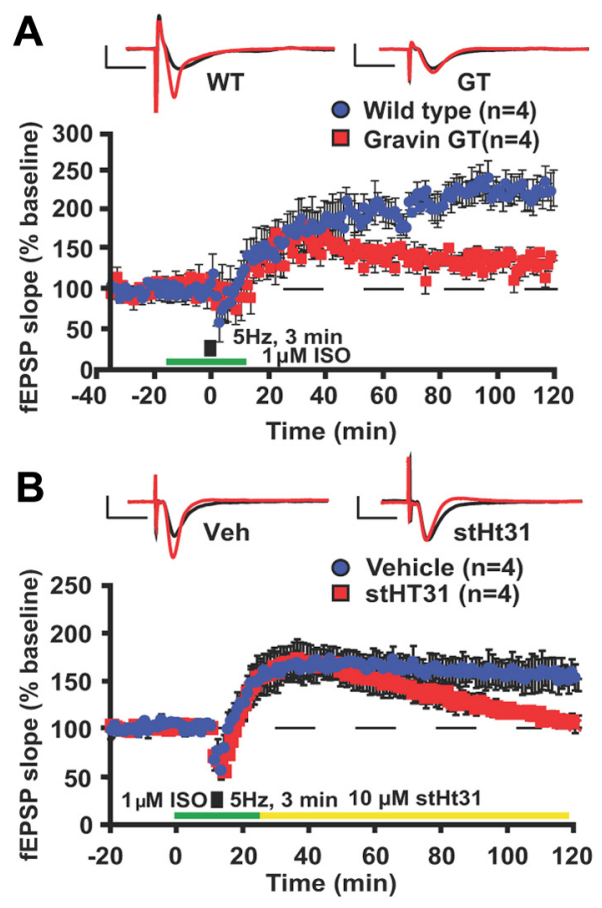

Figure 3. Hippocampal synaptic plasticity induced by $\beta 2$-adrenergic receptor activation is impaired in gravin GT mice. $A$, Hippocampal plasticity induced by pairing $1 \mu \mathrm{M} I S O$ with $5 \mathrm{~Hz}$ train of LFS for 3 min was impaired in slices from gravin GT mice (Kruskal-Wallis ANOVA, $p<$ 0.05). $\boldsymbol{B}$, The maintenance of hippocampal synaptic plasticity induced by pairing $1 \mu \mathrm{m} \mathrm{ISO} \mathrm{with}$ a $5 \mathrm{~Hz}$ train of LFS for 3 min was impaired by disrupting PKA anchoring using membranepermeable stearated Ht31 after the induction of plasticity (Kruskal-Wallis ANOVA, $p<0.05$ ). In all sample sweeps, black traces indicate baseline, and red traces were acquired $2 \mathrm{~h}$ after stimulation. Calibration: $2 \mathrm{mV}, 10 \mathrm{~ms}$. Error bars indicate SEM.

These data indicate that the loss of gravin- $\alpha$ impairs synaptic plasticity that requires $\beta 2$-AR occupancy.

To determine whether PKA anchoring is required during the maintenance phase of this form of synaptic plasticity, we repeated this experiment but now treating slices from WT mice with the PKA-anchoring disrupting peptide Ht31 (Carr et al., 1992; Vijayaraghavan et al., 1997; Huang et al., 2006). Bath application of stHt31 $(10 \mu \mathrm{M})$ started immediately following ISO treatment and was continued throughout the recording (Fig. $3 B$ ). We found that stHt31 treatment during the maintenance phase of synaptic plasticity induced by pairing $1 \mu \mathrm{M}$ ISO with LFS ( $5 \mathrm{~Hz}$ for $3 \mathrm{~min}$ ) was sufficient to impair this form of plasticity (both groups, $n=4$; Kruskal-Wallis ANOVA, $p<0.05$; Fig. $3 B$ ). The mean fEPSP slope over the last $20 \mathrm{~min}$ of the recording was significantly reduced due to treatment with stHt31 (vehicle treatment, $154.9 \pm$ 13.5\%; stHt31, $98.9 \pm 4.2 \%$; Mann-Whitney $U$ test, $p=0.029$ ). This reduction was not observed with bath application of stearated pseudo-stHt31 control peptide (data not shown). These findings suggest that this form of $\beta 2$-AR-mediated plasticity requires PKA anchoring during the maintenance phase.

\section{Gravin GT mice exhibit impaired spatial memory in the Morris water maze}

During training in the hippocampus-dependent spatial version of the Morris water maze (Schenk and Morris, 1985), mice have to learn and remember the location of a hidden platform using distal environmental cues. Because inhibition of PKA-AKAP interactions impairs memory formation in the spatial version of the Morris water maze (Nie et al., 2007; Tunquist et al., 2008), we tested whether gravin GT mice had memory deficits in this task. 
Gravin GT mice $(n=17)$ and wild-type mice $(n=18)$ gradually learned to locate the hidden platform (two-way repeatedmeasures ANOVA, effect of day, $F_{(5,165)}=23.20, p=0.0001$; Fig. $4 A)$. However, gravin GT mice exhibited an overall reduced acquisition rate during training (two-way repeated-measures ANOVA, effect of genotype, $F_{(1,33)}=6.02, p=0.02$; Fig. $4 A$ ). Nonetheless, they eventually reached the hidden platform with similar latency compared with wild-type littermates. Control measurements confirmed that swim speed in the gravin GT mice was similar to that of wild-type littermates (WT, $22.6 \pm 1.1 \mathrm{~cm} / \mathrm{s}$; GT, $23.0 \pm 1.3 \mathrm{~cm} / \mathrm{s}$; Student's $t$ test, $p=0.831)$. Thigmotaxis was likewise not altered (WT, $15.4 \pm 5 \%$; GT, $18.3 \pm 4 \%$; Student's $t$ test, $p=0.616$ ).

During the probe trial $24 \mathrm{~h}$ after training, gravin GT mice exhibited a reduced preference for the target quadrant (twofactor ANOVA, interaction between genotype and platform, $F_{(3,99)}=7.829, p=0.0001$; Fig. 4 B). Post hoc analyses confirmed that wild-type mice had a strong preference for the target quadrant (Tukey's test, $p<0.001$, target vs other quadrants). In contrast, gravin GT mice extended their search for the platform to the adjacent quadrants (Tukey's test, $p>0.1$, target vs adjacent quadrants). Wild-type mice also exhibited more platform crossings than gravin GT mice (WT, $6.4 \pm 0.71$; GT, $4.29 \pm 0.63$; Student's $t$ test, $p=0.036$ ). Together, these findings indicate that loss of gravin- $\alpha$ attenuates spatial memory in the Morris water maze. Gravin GT mice were not impaired in the hippocampusindependent visible platform version of the same task (WT, $n=$ 6; GT, $n=5$; two-way repeated-measures ANOVA, effect of genotype, $F_{(1,18)}=0.056, p=0.813$; interaction between genotype and day, $F_{(2,18)}=0.240, p=0.743$; Fig. $\left.4 C\right)$. To determine whether the spatial memory deficits were a consequence of alterations in locomotor behavior, we assessed motor coordination in a new batch of gravin GT mice using the rotarod test. Both wild types and gravin GT mice gradually increased the time spent on the rotating rod (two-way repeated-measures ANOVA, effect of day, $F_{(2,28)}=15.634, p=0.0001$; Fig. $\left.4 D\right)$. No effect of genotype was found (two-way repeated-measures ANOVA, effect of genotype, $\left.F_{(1,14)}=0.001, p=0.953\right)$. Furthermore, gravin GT mice and wild-type littermates spent a similar time in the open arms of the zero maze (Student's $t$ test, $p=0.694$; Fig. $4 E$ ) and a similar time in the center of the open field (Student's $t$ test, $p=0.388$; Fig. $4 F$ ), indicating that the spatial deficits observed in the gravin GT mice were not a consequence of alterations in exploratory or anxiety behavior.

\section{Gravin GT mice have long-term memory impairments in the object-place recognition task, but not in the novel object recognition task}

To evaluate whether other forms of hippocampus-dependent memory were impaired, we tested a naive batch of animals in the object-place recognition task, a hippocampus-dependent paradigm that examines the ability of animals to discriminate between familiar and novel spatial locations of objects (Oliveira et al., $2010)$. During training, both gravin GT mice $(n=16)$ and wildtype littermates $(n=17)$ gradually decreased exploration of the objects (two-way repeated-measures ANOVA, effect of genotype, $\left.F_{(1,31)}=4.924, p=0.034\right)$. Gravin GT mice spent considerably more time exploring the objects than wild-type mice during all three training sessions (session 1, WT, $29.1 \pm 3.2 \mathrm{~s}$, GT, $38.7 \pm$ $4.0 \mathrm{~s}$; session 2, WT, $17.8 \pm 1.5 \mathrm{~s}$, GT, $23.0 \pm 2.7 \mathrm{~s}$; session 3, WT, $14.1 \pm 1.1 \mathrm{~s}, \mathrm{GT}, 21.8 \pm 3.1 \mathrm{~s}$; two-way repeated-measures ANOVA effect of session, $\left.F_{(2,62)}=50.790, p=0.001\right)$. Twentyfour hours after the last training session, one of the three objects was moved to a novel location and mice were allowed to explore the objects. A two-way ANOVA revealed a significant interaction effect between genotype and object $\left(F_{(1,31)}=7.136, p=0.012\right.$; Fig. $4 G$ ). Wild-type mice significantly increased the time spent on exploring the displaced object while decreasing the time exploring the non-displaced objects (paired samples $t$ test, $p=0.003$; Fig. $4 G$ ). In contrast, gravin GT mice decreased the time spent exploring both displaced and non-displaced object (paired samples $t$ test, $p=0.518$; Fig. $4 G$ ). No difference in locomotor speed was observed between mutant and wild-type mice (WT, $51.3 \pm$ $6.5 \mathrm{~mm} / \mathrm{s}$; GT, $47.7 \pm 5.3 \mathrm{~mm} / \mathrm{s}$; Student's $t$ test, $p=0.651$ ). These findings indicate that the formation of object-place memories is impaired in the gravin GT mice.

To determine whether gravin GT mice also have a deficit in detecting object novelty, gravin GT mice $(n=8)$ and wild-type littermates $(n=8)$ were trained and tested in the novel object recognition task, a task that is based on the animal's spontaneous preference for novelty (Ennaceur and Delacour, 1988). The training conditions we used do not require an intact hippocampus (Winters et al., 2004; Oliveira et al., 2010). During training, both groups spent a similar amount of time exploring both objects (WT, $48.6 \pm 8.8 \mathrm{~s}$; GT, $58.4 \pm 8.6 \mathrm{~s}$; Student's $t$ test, $p=0.410$ ). Twenty-four hours after training, mice were reintroduced to the arena and reexposed to two objects, a familiar object and a new object. Both groups preferentially explored the novel object (twofactor ANOVA, $F_{(1,28)}=5.806, p=0.023$; Fig. $\left.4 H\right)$. No effect of genotype (ANOVA, $F_{(1,28)}=0.006, p=0.936$ ) or interaction effect between genotype and object (ANOVA, $F_{(1,28)}=0.661, p=$ 0.423 ) was found. These data indicate that the formation of longterm memories for objects does not require gravin- $\alpha$ signaling complexes.

\section{Gravin GT mice have long-term memory impairments in contextual and tone-cued fear conditioning task}

Next, we tested whether gravin GT mice showed an impairment in hippocampus-dependent contextual fear conditioning (Logue et al., 1997). During training, both groups (WT, $n=10$; GT, $n=$ 8) showed similar preshock and postshock freezing levels (Student's $t$ test, $p>0.2$ in both cases) (data not shown). One hour after training, both groups were reexposed to the training context and showed similar freezing levels (WT, $28.3 \pm 4.2 \%$; GT, $31.2 \pm$ 5.4\%; Student's $t$ test, $p=0.679$; Fig. $4 I$ ), indicating that gravin GT mice form normal short-term contextual fear memories. To test whether the formation of long-term contextual fear memories was attenuated, we repeated the contextual fear conditioning experiment with a new batch of mice. Both groups $(n=8$ each) again showed similar preshock and postshock freezing levels during training (Student's $t$ test, $p>0.5$ in both cases) (data not shown). Twenty-four hours after training, mice were reexposed to the same context. Gravin GT mice showed reduced freezing levels (33.2 $\pm 5.8 \%$ ) compared with wild-type littermates (54.5 \pm $5.6 \%$ ) (Student's $t$ test, $p=0.019$; Fig. $4 I$ ). Because PKA anchoring is also required for amygdala-dependent auditory fear memories (Moita et al., 2002), we subjected a third batch of mice to cued fear conditioning that critically depends on the amygdala. Both groups (WT, $n=18$; GT, $n=19$ ) showed similar freezing levels when exposed to the context, tone [the conditioned stimulus (CS) ], and directly after receiving the shock (Student's $t$ test, $p>0.2$ for all three cases) (data not shown). Twenty-four hours after conditioning, mice were exposed to a novel context and reexposed to the tone. Exposure to the novel context induced similar freezing levels in both groups (Student's $t$ test, $p=0.410$; Fig. $4 J)$. However, gravin GT mice showed reduced freezing levels 
A

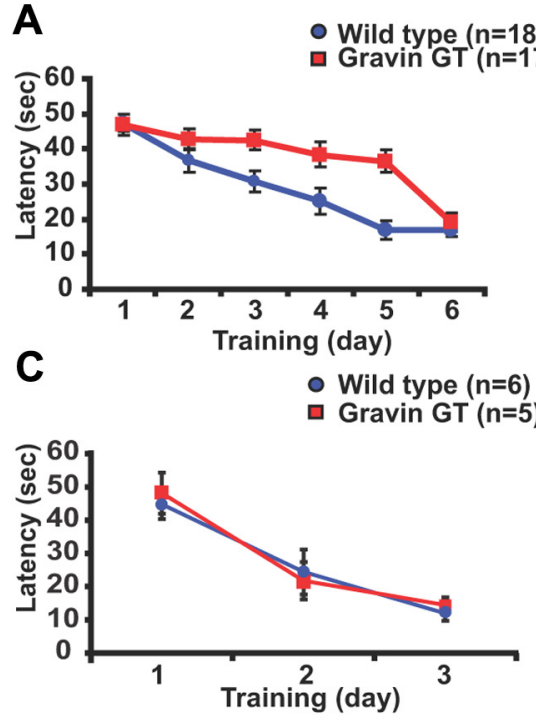

B

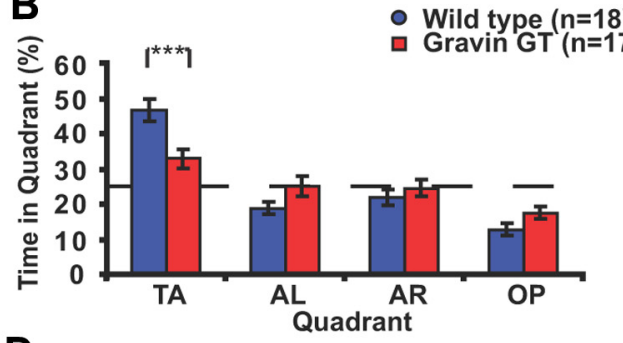

D

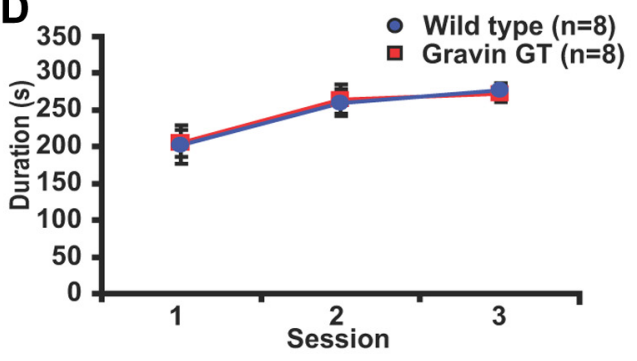

$E$

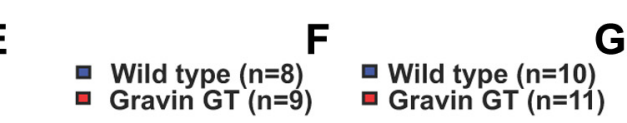

G 3x Training Testing
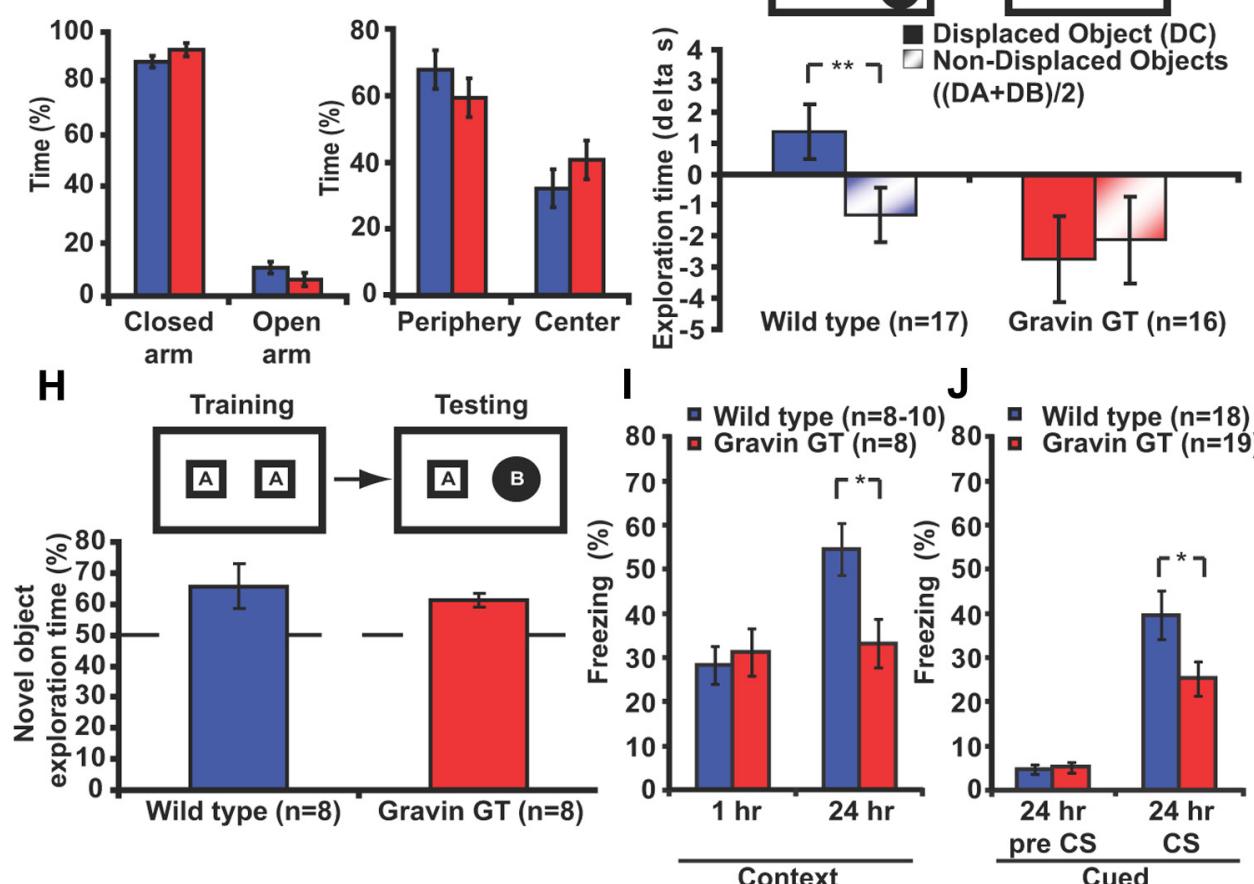

$J$

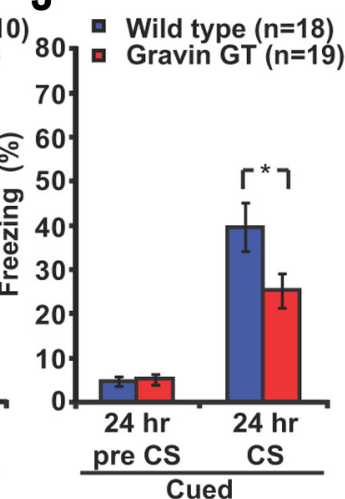

Figure 4. Long-term memory formation is impaired in gravin GT mice. $A$, In the spatial version of the water maze, gravin GT mice exhibited impairments during training (two-way repeatedmeasures ANOVA, effect of genotype, $F_{(1,33)}=6.02, p=0.02$ ) but eventually reached the hidden platform with a latency similar to wild-type littermates (independent-samples $t$ test, $p=0.523$ ). $B$, During the probe trial, wild-type mice preferentially searched in the target quadrant ( $p o s t$ hoc Tukey's test, $p<0.001$ ) in contrast to gravin GT mice (post hoc Tukey's test, $p>0.1$, target vs adjacent quadrants). C, Gravin GT mice were not different from wild-type mice on the visible platform version of the maze (two-way repeated-measures ANOVA, $F_{(1,18)}=0.056, p=0.813$; interaction between genotype and day, $\left.F_{(2,18)}=0.240, p=0.743\right)$. $\boldsymbol{D}$, Motor coordination as assessed by the rotarod test was not altered in the gravin GT mice. Both groups gradually increased the time spent on the rotating rod (two-way repeated-measures ANOVA, effect of day, $F_{(2.28)}=15.634, p=0.0001$ ). No effect of genotype was found (two-way repeated-measures ANOVA effect of genotype, $\left.F_{(1,14)}=0.001, p=0.953\right)$. E, Gravin GT mice spent a similar time in the open arms of the zero maze as wild-type mice (Student's $t$ test, $\left.p=0.694\right)$. $F$, Gravin GT mice spent a similar time in the center of the open field as wild-type mice (Student's t test, $p=0.388$ ). G, During the test session in the object-place recognition task, wild-type mice exhibited increased exploration time for the displaced object but decreased exploration time for the non-displaced objects (paired $t$ test, $p=0.003$ ). Gravin GT mice exhibited reduced exploration times for both displaced and non-displaced objects (paired $t$ test, $p=0.518$ ). $\boldsymbol{H}$, During the test session in the novel object recognition task, both wild-type and gravin GT mice preferentially explored the novel object (two-factor ANOVA $F_{(1,28)}$ $=5.806, p=0.023)$. No genotype or interaction effect between genotype and object was found (ANOVA, $F_{(1,28)}=0.006, p=0.936 ;$ ANOVA, $F_{(1,28)}=0.661, p=0.423$, respectively). The dotted line indicates no preference. I, Mice were trained in the contextual fear conditioning paradigm. Wild-type and gravin GT mice showed similar freezing levels during the retention test $1 \mathrm{~h}$ after training (Student's $t$ test, $p=0.679$ ), while gravin GT mice showed reduced freezing levels during the retention test $24 \mathrm{~h}$ after conditioning (Student's $t$ test, $p=0.019$ ). J, In the cued-fear conditioning paradigm, gravin GT mice showed reduced freezing levels during the test session $24 \mathrm{~h}$ after training (Student's $t$ test, $p=0.023$ ). TA, Target; AL, adjacent left; $A R$, adjacent right; OP, opposite. * $p<$ $0.05 ;{ }^{* *} p=0.003 ;{ }^{* * *} p<0.001$. Error bars indicate SEM. 
A

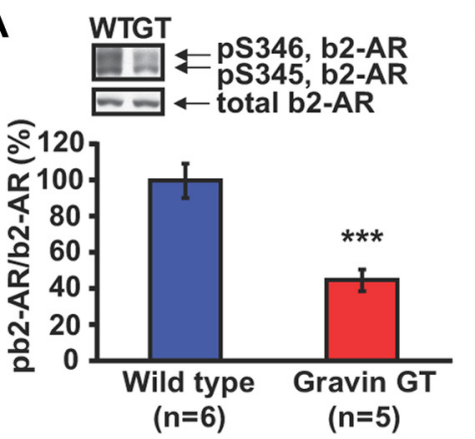

C
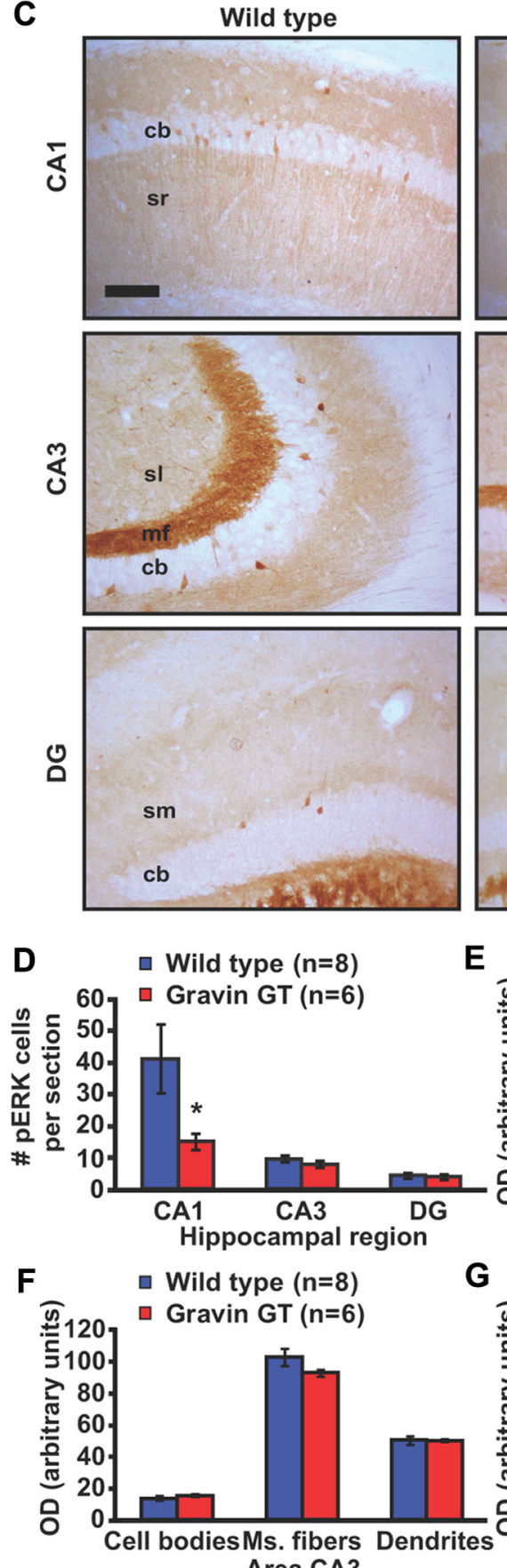
Area CA3

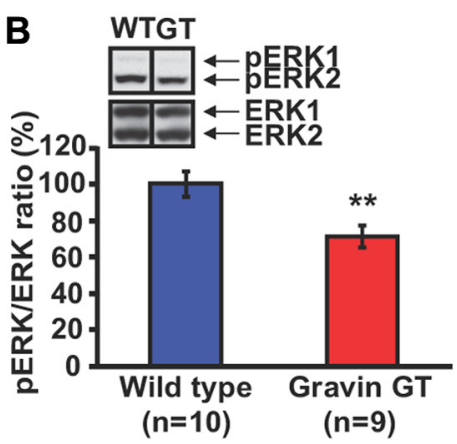

Gravin GT
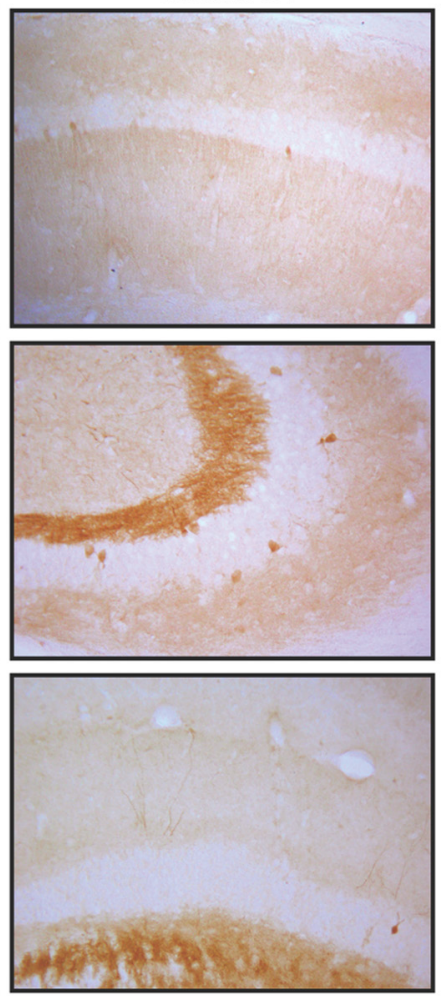

E

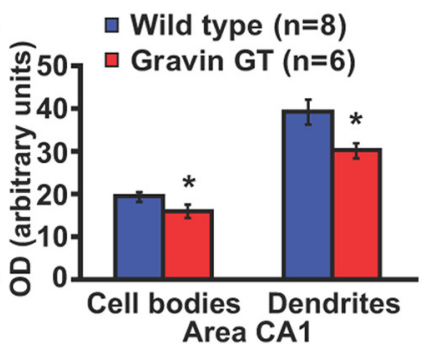

G

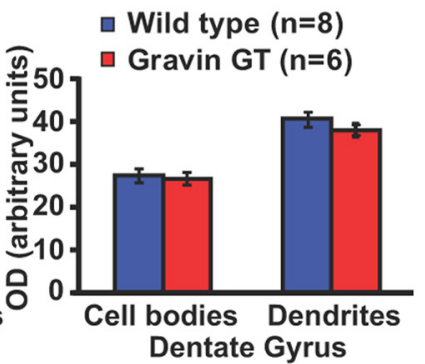

Figure 5. Phosphorylation of the $\beta 2$-adrenergic receptor and ERK1/2 is reduced in the hippocampus of gravin GT mice 30 min after fear conditioning. $\boldsymbol{A}$, Hippocampal $\beta 2$-adrenergic receptor phosphorylation levels at the serine 345 and serine 346 sites are reduced in gravin GT mice 30 min after fear conditioning (WT, $100.0 \pm 9.6 \%$; GT, $44.8 \pm 6.2 \%$; Student's $t$ test, $p=0.001) . \boldsymbol{B}$, Hippocampal pERK1/2 levels are reduced in gravin GT mice 30 min after fear conditioning (WT, $100.0 \pm 7.1 \%$; GT, $71.0 \pm 5.9 \%$;

during the reexposure to the CS (WT, $39.6 \pm 5.5 \%$; GT, $25.2 \pm 3.9 \%$; Student's $t$ test, $p=0.023$; Fig. $4 J$ ), indicating that loss of gravin- $\alpha$ impairs cued fear conditioning.

\section{Phosphorylation of the $\beta 2-\mathrm{AR}$ and ERK1/2 is reduced after fear conditioning in gravin GT mice} Because gravin GT mice show deficits in the formation of hippocampus-dependent long-term memories, we next determined whether learning-induced activation of the $\beta 2$-AR signaling pathway was altered in the gravin GT mice. Occupancy of the $\beta 2$-AR leads to G $\alpha$ s-mediated activation of PKA, which in turn phosphorylates the receptor at serine 345 and serine 346 (Hausdorff et al., 1989). To determine whether the loss of gravin- $\alpha$ attenuates $\beta 2$-AR phosphorylation by PKA in vivo, mice underwent contextual fear conditioning and hippocampal tissue was collected $30 \mathrm{~min}$ after training. Western blot analyses indicated that gravin GT mice showed reduced $\beta 2$-AR phosphorylation at both serine sites (WT, $100.0 \pm 9.6 \%$; GT, $44.8 \pm$ $6.2 \%$; Student's $t$ test, $p=0.001$; Fig. $5 A$ ). Because $\beta 2$-AR phosphorylation was not affected in experimentally naive gravin GT mice (WT, $100.0 \pm 1.3 \%$; GT, $98.8 \pm$ $0.8 \%$; Student's $t$ test, $p=0.448$ ), these data suggest that learning-induced $\beta 2-\mathrm{AR}$ phosphorylation by PKA is impaired in gravin GT mice. The reduction in $\beta 2$-AR phosphorylation by PKA 30 min after fear conditioning was also not a reflection of an overall reduction of PKA activity due to the loss of gravin- $\alpha$ because global PKA activity in hippocampal lysates was not at-

Student's $t$ test, $p=0.006)$. C, Immunohistochemistry for pERK in area CA1, CA3, and DG from sections representative of wild-type mice and gravin GT mice 30 min after fear conditioning training. Note the reduced pERK1/2 labeling in area CA1. cb, Cell bodies; sr, stratum radiatum; $\mathrm{sl}$, stratum lucidum; mf, mossy fibers; sm, stratum moleculare. Scale bar, $40 \mu \mathrm{m}$. D, The number of pERK1/2-positive cells in hippocampal subregions of wild-type and gravin GT mice 30 min after fear conditioning training. The number of pERK-positive cells in area CA1 was significantly reduced in gravin GT mice (Student's $t$ test, $p=0.006)$. $\boldsymbol{E}$, Optical density measurements of pERK $1 / 2 \mathrm{im}$ munoreactivity in the cell body layer and stratum radiatum of area CA1 in wild-type mice and gravin GT mice. pERK1/2 immunoreactivity was significantly reduced in CA1 stratum radiatum (Student's $t$ test, $p=0.031$ ) and CA1 cell body layer (Student's $t$ test, $p=0.034) . F$, Optical density measurements of pERK1/2 immunoreactivity in the cell body layer, mossy fibers, and stratum lucidum of area CA3 in wild-type mice and gravin GT mice. G, Optical density measurements of pERK1/2 immunoreactivity in the cell body layer and molecular layer of the DG in wild-type mice and gravin GT mice. ${ }^{*} p<0.05$, ${ }^{* *} p<0.01,{ }^{* * *} p=0.001$. Error bars indicate SEM. 

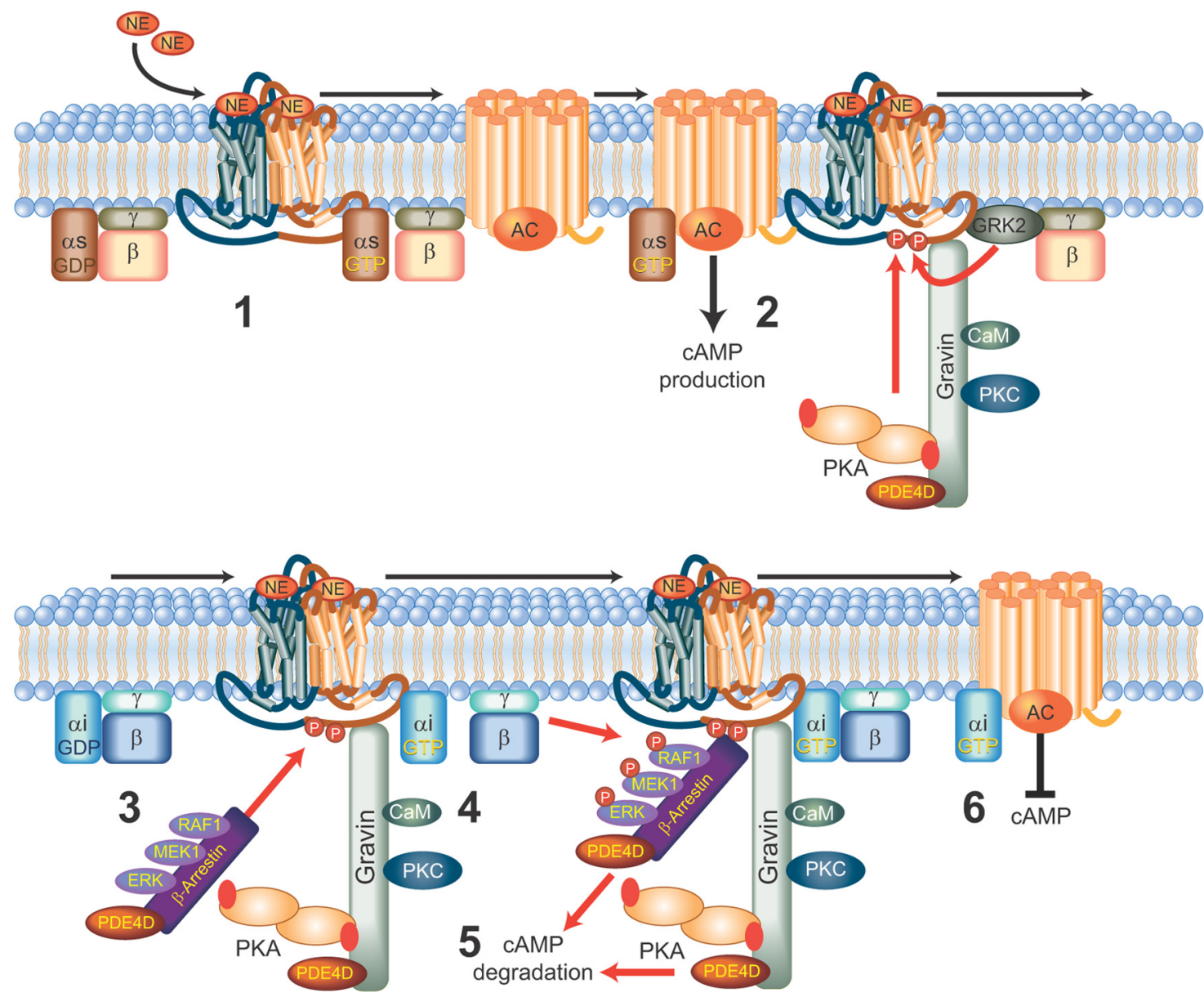

Figure 6. A potential mechanism illustrating the role of gravin complexes in $\beta 2$-adrenergic receptor signaling. Activation of the $\beta 2$-adrenergic receptor leads to the coupling with Gs proteins (1), the recruitment of gravin signaling complexes to the plasma membrane (Tao et al., 2003), and phosphorylation of the receptor by PKA (2) (Hausdorff et al., 1989). GRK2 initiates the desensitization process and recruitment of the $\beta$-arrestin signaling complex (Perry et al., 2002) (3). The $\beta 2$ adrenergic receptor switches coupling from Gs to Gi proteins leading to the activation of ERK1/2 (Daaka et al., 1997) (4). The $\beta$-arrestin signaling complex attenuates local cAMP signaling through the recruited PDE4D, which degrades cAMP (Baillie et al., 2003) (5), and by preventing Gs-mediated adenylate cyclase activation by the $\beta 2$-adrenergic receptor (Perry et al., 2002) (6).

tenuated in the gravin GT mice (WT, $n=7,100 \pm 5.9 \%$; GT, $n=$ $7,102 \pm 8.6 \%$; Student's $t$ test, $p=0.792)$. The latter observation is in concordance with previous studies showing that loss of PKA anchoring does not affect global PKA activity in hippocampal lysates (Nie et al., 2007; Weisenhaus et al., 2010). Next, we determined whether loss of gravin affects PKA-mediated phosphorylation of the AMPA receptor GluA1 serine 845 site. We found that the phosphorylation levels of this site were not altered in hippocampal lysates from wild-type and gravin GT mice 30 min after fear conditioning (WT, $n=7,100 \pm 5.9 \%$; GT, $n=7,99.9 \pm$ $5.9 \%$; Student's $t$ test, $p=0.996$ ). Together, these data suggest that loss of gravin- $\alpha$ affects the phosphorylation of specific substrates such as the $\beta 2$-AR rather than leading to a global reduction in PKA function. PKA-mediated $\beta 2$-AR phosphorylation at serine 345 and serine 346 switches coupling of the $\beta 2-\mathrm{AR}$ from $\mathrm{G} \alpha$ s to $\mathrm{G} \alpha \mathrm{i}$-proteins leading to the activation of the ERK1/2 pathway (Daaka et al., 1997; Baillie et al., 2003). Thus, reductions in the phosphorylation of $\beta 2$-AR phosphorylation at serine 345 and serine 346 would be predicted to reduce the activation of ERK1/2. Indeed, we found that phospho levels of ERK1/2 were significantly decreased in gravin GT mice $30 \mathrm{~min}$ after fear conditioning training (WT, $100.0 \pm 7.1 \%$; GT, $71.0 \pm 5.9 \%$; Student's $t$ test, $p=0.006$; Fig. $5 B$ ). This decrease in hippocampal ERK1/2 phosphorylation was not observed in experimentally naive mice (WT, $n=15,100 \pm 3.8 \%$; GT, $n=14,114.7 \pm 8.3 \%$; Student's $t$ test, $p=0.137)$. A study by Sindreu et al. (2007) suggested that fear conditioning induces changes in pERK1/2 specifically in hippocampal area CA1. Therefore, we assessed whether the reduction in pERK1/2 levels in the gravin GT mice was restricted to area CA1. Mice were trained in the fear-conditioning task and transcardially perfused $30 \mathrm{~min}$ after training, and dorsal hippocampal sections were stained for $\mathrm{pERK} 1 / 2$. The largest number of pERK1/2-positive cells in the dorsal hippocampus was observed in area CA1 (Fig. 5C,D). Gravin GT mice showed significantly fewer pERK1/2-positive cells in area CA1 (WT, $41.2 \pm$ 10.7\%; GT, $15.1 \pm 2.7 \%$; Student's $t$ test, $p=0.006$; Fig. $5 D$ ). No significant changes in pERK1/2-positive cells were observed in area CA3 or in the DG. Optical density measurements in hippocampal subregions showed reduced pERK1/2 labeling in stratum radiatum ( $\mathrm{sr}$ ) of area CA1 (WT, $39.2 \pm 2.9 \%$; GT, $30.3 \pm$ $1.7 \%$; Student's $t$ test, $p=0.031$; Fig. $5 E$ ) and the CA1 cell body layer (WT, $19.5 \pm 1.1 \%$; GT, $15.8 \pm 1.4 \%$; Student's $t$ test, $p=$ 0.034; Fig. $5 E$ ). No significant changes in staining intensity were observed in CA3 cell bodies (WT, $12.4 \pm 1.7 \%$; GT, $15.2 \pm 1.1 \%$; Student's $t$ test, $p=0.422$; Fig. $5 F$ ), mossy fibers (WT, $102.6 \pm$ 5.19\%; GT, $92.7 \pm 2.3 \%$; Student's $t$ test, $p=0.117$; Fig. $5 F)$, or stratum lucidum (WT, $50.0 \pm 2.7 \%$; GT, $49.9 \pm 0.7 \%$; Student's $t$ test, $p=0.979$; Fig. $5 F$ ). Likewise, no changes were observed in 
the DG cell bodies (WT, $27.3 \pm 1.7 \%$; GT, $26.7 \pm 1.6 \%$; Student's $t$ test, $p=0.803$; Fig. $5 G$ ) or molecular layer (WT, $40.5 \pm 1.1 \%$; GT, $38.0 \pm 1.4 \%$; Student's $t$ test, $p=0.193$; Fig. $5 G$ ). Together, these results indicate that training-induced ERK1/2 activation in hippocampal area CA1 is impaired in gravin GT mice.

\section{Discussion}

Coordination of excitatory synaptic signaling events is a complex process that relies on the spatial and temporal segregation of cellular signaling pathways within the neuron. This is achieved in part by AKAPs that compartmentalize unique macromolecular complexes consisting of PKA and other signaling molecules including phosphatases, PDEs, and targets of PKA at defined synaptic locations (Welch et al., 2010). This intricate network of protein-protein interactions provides a molecular mechanism that allows different extracellular signals to engage spatially distinct pools of kinases. Although studies have implicated PKA signaling in long-lasting forms of LTP and memory, the identity of the AKAP(s) that coordinates pools of PKA critically involved in synaptic plasticity and memory formation is less well understood. Here, we show that selective loss of the $\alpha$-isoform of gravin impairs long-lasting forms of hippocampal synaptic plasticity including those that require $\beta 2$-AR activation as well as the formation of long-term memories that require the hippocampus or amygdala. Furthermore, our biochemical studies reveal that the loss of gravin- $\alpha$ attenuates hippocampal $\beta 2$-AR phosphorylation by PKA and reduces learning-induced activation of ERK1/2 in area CA1 of the dorsal hippocampus.

Our observation that the loss of gravin- $\alpha$ reduces PKAmediated $\beta 2$-AR phosphorylation in the hippocampus tallies with cell culture studies. These studies have shown that activation of the $\beta 2$-AR initiates the recruitment of gravin to plasma membrane sites (Tao et al., 2003), the phosphorylation of gravin by PKA, and association of PKA with the $\beta 2$-AR (Shih et al., 1999; Lin et al., 2000). However, we have significantly extended these biochemical studies and provide a physiological context for the findings by showing that distinct forms of hippocampal LTP that require $\beta 2$-ARs and PKA anchoring are impaired in gravin GT mice. Importantly, we have found that PKA anchoring is required for a form of synaptic plasticity that requires low-frequency electrical stimulation in combination with activation of $\beta 2$-ARs, consistent with this hypothesized role of gravin in regulating $\beta 2-\mathrm{AR}$ function during sustained activation. Thus, gravin- $\alpha$ is a key organizational component of PKA and $\beta 2$-AR-mediated signaling in hippocampal neurons and allowed us to propose that disruption of the $\beta 2$-AR-controlled component of hippocampal synaptic plasticity and long-term memories could be due to the observed loss of local PKA function (Fig. 6). Future studies using pharmacological reagents that modulate specific components of the $\beta 2$-AR signaling complex (Kahsai et al., 2011) are needed to further unravel the role that $\beta 2$-ARs play in hippocampal LTP and memory. Because our Ht31 experiment suggests that PKA anchoring is required during the maintenance phase of LTP, it will also be important to elucidate whether blocking PKA activity and $\beta 2$-AR function selectively during the maintenance phase is sufficient to impair long-lasting forms of LTP or behavior and memory.

As with other AKAPs, gravin is a multivalent scaffolding protein that not only binds PKA but also binds PKC and calmodulin, and recruits PDE4D to the $\beta 2-\mathrm{AR}$ (Nauert et al., 1997; Lin and Gelman, 2002; Willoughby et al., 2006), suggesting that loss of gravin- $\alpha$ not only reduces the localization of cAMP responsive enzymes such as PKA and PDE4D (Houslay and Baillie, 2003) but also abrogates the efficacy of other signaling molecules that regulate $\beta 2$-AR function (Fig. 6). These include PKC, another enzyme that can phosphorylate GRK2 promoting desensitization of the $\beta 2$-ARs (Kohout and Lefkowitz, 2003) (Fig. 6), and calmodulin, which relays the increases in intracellular $\mathrm{Ca}^{2+}$ into activation or inhibition of downstream enzymes. The latter has been proposed to be a signal integrator for synaptic plasticity (Xia and Storm, 2005). In future experiments, it will be interesting to determine whether gravin-mediated compartmentalization of PKC and calmodulin contribute to synaptic plasticity important for memory. Nevertheless, our current study suggests that the $\alpha$-isoform of gravin is particularly important for PKA signaling and for the activation of ERK1/2.

Previous studies to define the AKAP complexes involved in synaptic plasticity and memory processes have been complicated by non-mnemonic behavioral side effects and neuroanatomical abnormalities. AKAP150-null mice exhibit a reduction in motor coordination (Tunquist et al., 2008), and mice lacking the PKA binding site from MAP2B have an abnormal CA1 architecture (Khuchua et al., 2003). In contrast, loss of gravin- $\alpha$ impairs longterm memory formation, without affecting motor coordination, anxiety, exploratory behavior, or hippocampal architecture. This makes it unlikely that the observed memory deficits observed here are an indirect consequence of the loss of gravin- $\alpha$ during development. Rather, it supports the notion that gravin- $\alpha$ mediated compartmentalization of signaling complexes during adulthood is required to maintain normal synaptic plasticity and memory.

ERK1/2 signaling is required for long-lasting forms of LTP (Impey et al., 1998; Patterson et al., 2001) and the formation of long-lasting memories (Davis and Laroche, 2006). More specifically, fear conditioning training activates the ERK pathway in a subset of hippocampal neurons specifically in area CA1 (Sindreu et al., 2007), and blocking ERK1/2 activity in hippocampal area CA1 during the consolidation window prevents the formation of long-term memories (Athos et al., 2002). We discovered that loss of gravin- $\alpha$ attenuates the formation of hippocampus-dependent long-term memories (Fig. 4) and impairs learning-induced activation of ERK1/2 pathway in area CA1 of the hippocampus (Fig. $5)$. These observations support the idea that gravin signaling complexes orchestrate learning-induced ERK1/2 activation in the hippocampus important for memory consolidation. $\beta 2-\mathrm{AR}$ phosphorylation by PKA is a prerequisite for activation of the ERK1/2 pathway by $\beta 2$-ARs (Daaka et al., 1997; Baillie et al., 2003). Therefore, our finding that $\beta 2$-AR phosphorylation was reduced in hippocampal neurons after fear conditioning training (Fig. 5) suggests that loss of gravin-mediated PKA phosphorylation of $\beta 2$-AR may hamper the activation of the ERK1/2 pathway (Fig. 6). However, it should be noted that $\beta 2$-ARs can also activate the ERK1/2 pathway through PKA-independent signaling mechanisms (Schmitt and Stork, 2000). Furthermore, cAMP, PKA, and ERK1/2 signaling interact in other ways (Gloerich and Bos, 2010).

This study is the first to show that gravin- $\alpha$ controls PKAdependent forms of hippocampal synaptic plasticity and a $\beta 2$-AR-mediated form of synaptic plasticity that requires lowfrequency electrical stimulation in combination with activation of $\beta 2$-ARs, regulates hippocampal ERK1/2 signaling, and is required for specific forms of long-term memory. Furthermore, we demonstrate that PKA anchoring is critical for the maintenance of $\beta 2$-AR-mediated synaptic plasticity. Our studies not only implicate gravin- $\alpha$ in the subcellular targeting of PKA but also reveal that this particular macromolecular signaling complex is critical 
for the cellular and biochemical processes underlying long-term memory storage. By linking the glutamatergic and noradrenergic signaling pathways, gravin signaling complexes are able to orchestrate the formation of long-term changes in neuronal function.

\section{References}

Abel T, Nguyen PV, Barad M, Deuel TA, Kandel ER, Bourtchouladze R (1997) Genetic demonstration of a role for PKA in the late phase of LTP and in hippocampus-based long-term memory. Cell 88:615-626. CrossRef Medline

Athos J, Impey S, Pineda VV, Chen X, Storm DR (2002) Hippocampal CREmediated gene expression is required for contextual memory formation. Nat Neurosci 5:1119-1120. CrossRef Medline

Atkins CM, Selcher JC, Petraitis JJ, Trzaskos JM, Sweatt JD (1998) The MAPK cascade is required for mammalian associative learning. Nat Neurosci 1:602-609. CrossRef Medline

Baillie GS, Sood A, McPhee I, Gall I, Perry SJ, Lefkowitz RJ, Houslay MD (2003) beta-Arrestin-mediated PDE4 cAMP phosphodiesterase recruitment regulates beta-adrenoceptor switching from Gs to Gi. Proc Natl Acad Sci U S A 100:940-945. CrossRef Medline

Banker GA, Cowan WM (1977) Rat hippocampal neurons in dispersed cell culture. Brain Res 126:397-425. CrossRef Medline

Buzsáki G (2005) Theta rhythm of navigation: link between path integration and landmark navigation, episodic and semantic memory. Hippocampus 15:827-840. CrossRef Medline

Camus A, Mesbah K, Rallu M, Babinet C, Barra J (2001) Gene trap insertion reveals two open reading frames in the mouse SSeCKS gene: the form predominantly detected in the nervous system is suppressed by the insertion while the other, specific of the testis, remains expressed. Mech Dev 105:79-91. CrossRef Medline

Carr DW, Stofko-Hahn RE, Fraser ID, Cone RD, Scott JD (1992) Localization of the cAMP-dependent protein kinase to the postsynaptic densities by A-kinase anchoring proteins. Characterization of AKAP 79. J Biol Chem 267:16816-16823. Medline

Colledge M, Dean RA, Scott GK, Langeberg LK, Huganir RL, Scott JD (2000) Targeting of PKA to glutamate receptors through a MAGUK-AKAP complex. Neuron 27:107-119. CrossRef Medline

Daaka Y, Luttrell LM, Lefkowitz RJ (1997) Switching of the coupling of the beta2-adrenergic receptor to different $G$ proteins by protein kinase A. Nature 390:88-91. CrossRef Medline

Davis S, Laroche S (2006) Mitogen-activated protein kinase/extracellular regulated kinase signalling and memory stabilization: a review. Genes Brain Behav 5 [Suppl 2]:61-72. CrossRef Medline

Ennaceur A, Delacour J (1988) A new one-trial test for neurobiological studies of memory in rats. 1: Behavioral data. Behav Brain Res 31:47-59. CrossRef Medline

Frey U, Huang YY, Kandel ER (1993) Effects of cAMP simulate a late stage of LTP in hippocampal CA1 neurons. Science 260:1661-1664. CrossRef Medline

Gelinas JN, Tenorio G, Lemon N, Abel T, Nguyen PV (2008) Betaadrenergic receptor activation during distinct patterns of stimulation critically modulates the PKA-dependence of LTP in the mouse hippocampus. Learn Mem 15:281-289. CrossRef Medline

Gibbs ME, Summers RJ (2002) Role of adrenoceptor subtypes in memory consolidation. Prog Neurobiol 67:345-391. CrossRef Medline

Gloerich M, Bos JL (2010) Epac: defining a new mechanism for cAMP action. Annu Rev Pharmacol Toxicol 50:355-375. CrossRef Medline

Hagewoud R, Bultsma LJ, Barf RP, Koolhaas JM, Meerlo P (2011) Sleep deprivation impairs contextual fear conditioning and attenuates subsequent behavioural, endocrine and neuronal responses. J Sleep Res 20: 259-266. CrossRef Medline

Hausdorff WP, Bouvier M, O’Dowd BF, Irons GP, Caron MG, Lefkowitz RJ (1989) Phosphorylation sites on two domains of the beta 2-adrenergic receptor are involved in distinct pathways of receptor desensitization. J Biol Chem 264:12657-12665. Medline

Havekes R, Nijholt IM, Luiten PG, Van der Zee EA (2006) Differential involvement of hippocampal calcineurin during learning and reversal learning in a Y-maze task. Learn Mem 13:753-759. CrossRef Medline

Havekes R, Timmer M, Van der Zee EA (2007) Regional differences in hippocampal PKA immunoreactivity after training and reversal training in a spatial Y-maze task. Hippocampus 17:338-348. CrossRef Medline
Houslay MD, Baillie GS (2003) The role of ERK2 docking and phosphorylation of PDE4 cAMP phosphodiesterase isoforms in mediating cross-talk between the cAMP and ERK signalling pathways. Biochem Soc Trans 31:1186-1190. CrossRef Medline

Huang T, McDonough CB, Abel T (2006) Compartmentalized PKA signaling events are required for synaptic tagging and capture during hippocampal late-phase long-term potentiation. Eur J Cell Biol 85:635-642. CrossRef Medline

Huang YY, Kandel ER (1998) Postsynaptic induction and PKA-dependent expression of LTP in the lateral amygdala. Neuron 21:169-178. CrossRef Medline

Impey S, Obrietan K, Wong ST, Poser S, Yano S, Wayman G, Deloulme JC, Chan G, Storm DR (1998) Cross talk between ERK and PKA is required for $\mathrm{Ca}^{2+}$ stimulation of CREB-dependent transcription and ERK nuclear translocation. Neuron 21:869-883. CrossRef Medline

Kahsai AW, Xiao K, Rajagopal S, Ahn S, Shukla AK, Sun J, Oas TG, Lefkowitz RJ (2011) Multiple ligand-specific conformations of the beta2adrenergic receptor. Nat Chem Biol 7:692-700. CrossRef Medline

Kemp A, Manahan-Vaughan D (2008) Beta-adrenoreceptors comprise a critical element in learning-facilitated long-term plasticity. Cereb Cortex 18:1326-1334. CrossRef Medline

Khuchua Z, Wozniak DF, Bardgett ME, Yue Z, McDonald M, Boero J, Hartman RE, Sims H, Strauss AW (2003) Deletion of the N-terminus of murine map2 by gene targeting disrupts hippocampal cal neuron architecture and alters contextual memory. Neuroscience 119:101-111. CrossRef Medline

Kohout TA, Lefkowitz RJ (2003) Regulation of G protein-coupled receptor kinases and arrestins during receptor desensitization. Mol Pharmacol 63: 9-18. CrossRef Medline

Lin F, Wang Hy, Malbon CC (2000) Gravin-mediated formation of signaling complexes in beta 2-adrenergic receptor desensitization and resensitization. J Biol Chem 275:19025-19034. CrossRef Medline

Lin X, Gelman IH (2002) Calmodulin and cyclin D anchoring sites on the Src-suppressed C kinase substrate, SSeCKS. Biochem Biophys Res Commun 290:1368-1375. CrossRef Medline

Lin X, Tombler E, Nelson PJ, Ross M, Gelman IH (1996) A novel src- and ras-suppressed protein kinase $\mathrm{C}$ substrate associated with cytoskeletal architecture. J Biol Chem 271:28430-28438. CrossRef Medline

Logue SF, Paylor R, Wehner JM (1997) Hippocampal lesions cause learning deficits in inbred mice in the Morris water maze and conditioned-fear task. Behav Neurosci 111:104-113. CrossRef Medline

Lu Y, Allen M, Halt AR, Weisenhaus M, Dallapiazza RF, Hall DD, Usachev YM, McKnight GS, Hell JW (2007) Age-dependent requirement of AKAP150-anchored PKA and GluR2-lacking AMPA receptors in LTP. EMBO J 26:4879-4890. CrossRef Medline

McGaugh JL (2000) Memory-a century of consolidation. Science 287: 248-251. CrossRef Medline

Moita MA, Lamprecht R, Nader K, LeDoux JE (2002) A-kinase anchoring proteins in amygdala are involved in auditory fear memory. Nat Neurosci 5:837-838. CrossRef Medline

Nauert JB, Klauck TM, Langeberg LK, Scott JD (1997) Gravin, an autoantigen recognized by serum from myasthenia gravis patients, is a kinase scaffold protein. Curr Biol 7:52-62. CrossRef Medline

Nie T, McDonough CB, Huang T, Nguyen PV, Abel T (2007) Genetic disruption of protein kinase A anchoring reveals a role for compartmentalized kinase signaling in theta-burst long-term potentiation and spatial memory. J Neurosci 27:10278-10288. CrossRef Medline

Nijholt IM, Ostroveanu A, de Bruyn M, Luiten PG, Eisel UL, Van der Zee EA (2007) Both exposure to a novel context and associative learning induce an upregulation of AKAP150 protein in mouse hippocampus. Neurobiol Learn Mem 87:693-696. CrossRef Medline

O'Dell TJ, Connor SA, Gelinas JN, Nguyen PV (2010) Viagra for your synapses: enhancement of hippocampal long-term potentiation by activation of beta-adrenergic receptors. Cell Signal 22:728-736. CrossRef Medline

Oliveira AM, Hawk JD, Abel T, Havekes R (2010) Post-training reversible inactivation of the hippocampus enhances novel object recognition memory. Learn Mem 17:155-160. CrossRef Medline

Patterson SL, Pittenger C, Morozov A, Martin KC, Scanlin H, Drake C, Kandel ER (2001) Some forms of cAMP-mediated long-lasting potentiation are associated with release of BDNF and nuclear translocation of phospho-MAP kinase. Neuron 32:123-140. CrossRef Medline

Perry SJ, Baillie GS, Kohout TA, McPhee I, Magiera MM, Ang KL, Miller WE, 
McLean AJ, Conti M, Houslay MD, Lefkowitz RJ (2002) Targeting of cyclic AMP degradation to beta 2-adrenergic receptors by beta-arrestins. Science 298:834-836. CrossRef Medline

Qian H, Matt L, Zhang M, Nguyen M, Patriarchi T, Koval OM, Anderson ME, He K, Lee HK, Hell JW (2012) The $\beta 2$-adrenergic receptor supports prolonged theta tetanus-induced LTP. J Neurophysiol 107:2703-2712. CrossRef Medline

Schenk F, Morris RG (1985) Dissociation between components of spatial memory in rats after recovery from the effects of retrohippocampal lesions. Exp Brain Res 58:11-28. Medline

Schmitt JM, Stork PJ (2000) beta 2-adrenergic receptor activates extracellular signal-regulated kinases (ERKs) via the small G protein rap1 and the serine/threonine kinase B-Raf. J Biol Chem 275:25342-25350. CrossRef Medline

Shih M, Lin F, Scott JD, Wang HY, Malbon CC (1999) Dynamic complexes of beta2-adrenergic receptors with protein kinases and phosphatases and the role of gravin. J Biol Chem 274:1588-1595. CrossRef Medline

Sindreu CB, Scheiner ZS, Storm DR (2007) $\mathrm{Ca}^{2+}$-stimulated adenylyl cyclases regulate ERK-dependent activation of MSK1 during fear conditioning. Neuron 53:79-89. CrossRef Medline

Snyder EM, Colledge M, Crozier RA, Chen WS, Scott JD, Bear MF (2005) Role for A kinase-anchoring proteins (AKAPS) in glutamate receptor trafficking and long term synaptic depression. J Biol Chem 280: 16962-16968. CrossRef Medline

Streb JW, Kitchen CM, Gelman IH, Miano JM (2004) Multiple promoters direct expression of three AKAP12 isoforms with distinct subcellular and tissue distribution profiles. J Biol Chem 279:56014-56023. CrossRef Medline

Tao J, Malbon CC (2008) G-protein-coupled receptor-associated A-kinase anchoring proteins AKAP5 and AKAP12: differential signaling to MAPK and GPCR recycling. J Mol Signal 3:19. CrossRef Medline

Tao J, Wang HY, Malbon CC (2003) Protein kinase A regulates AKAP250 (gravin) scaffold binding to the beta2-adrenergic receptor. EMBO J 22: 6419-6429. CrossRef Medline

Tretter V, Revilla-Sanchez R, Houston C, Terunuma M, Havekes R, Florian C, Jurd R, Vithlani M, Michels G, Couve A, Sieghart W, Brandon N, Abel T, Smart TG, Moss SJ (2009) Deficits in spatial memory correlate with modified $\gamma$-aminobutyric acid type A receptor tyrosine phosphorylation in the hippocampus. Proc Natl Acad Sci U S A 106:20039-20044. CrossRef Medline

Tunquist BJ, Hoshi N, Guire ES, Zhang F, Mullendorff K, Langeberg LK, Raber J, Scott JD (2008) Loss of AKAP150 perturbs distinct neuronal processes in mice. Proc Natl Acad Sci U S A 105:12557-12562. CrossRef Medline
Van der Borght K, Havekes R, Bos T, Eggen BJ, Van der Zee EA (2007) Exercise improves memory acquisition and retrieval in the Y-maze task: relationship with hippocampal neurogenesis. Behav Neurosci 121:324-334. CrossRef Medline

Vecsey CG, Baillie GS, Jaganath D, Havekes R, Daniels A, Wimmer M, Huang T, Brown KM, Li XY, Descalzi G, Kim SS, Chen T, Shang YZ, Zhuo M, Houslay MD, Abel T (2009) Sleep deprivation impairs cAMP signalling in the hippocampus. Nature 461:1122-1125. CrossRef Medline

Vijayaraghavan S, Goueli SA, Davey MP, Carr DW (1997) Protein kinase A-anchoring inhibitor peptides arrest mammalian sperm motility. J Biol Chem 272:4747-4752. CrossRef Medline

Weisenhaus M, Allen ML, Yang L, Lu Y, Nichols CB, Su T, Hell JW, McKnight GS (2010) Mutations in AKAP5 disrupt dendritic signaling complexes and lead to electrophysiological and behavioral phenotypes in mice. PLoS One 5:e10325. CrossRef Medline

Welch EJ, Jones BW, Scott JD (2010) Networking with AKAPs: contextdependent regulation of anchored enzymes. Mol Interv 10:86-97. CrossRef Medline

Willoughby D, Wong W, Schaack J, Scott JD, Cooper DM (2006) An anchored PKA and PDE4 complex regulates subplasmalemmal cAMP dynamics. EMBO J 25:2051-2061. CrossRef Medline

Winder DG, Martin KC, Muzzio IA, Rohrer D, Chruscinski A, Kobilka B, Kandel ER (1999) ERK plays a regulatory role in induction of LTP by theta frequency stimulation and its modulation by beta-adrenergic receptors. Neuron 24:715-726. CrossRef Medline

Winters BD, Forwood SE, Cowell RA, Saksida LM, Bussey TJ (2004) Double dissociation between the effects of peri-postrhinal cortex and hippocampal lesions on tests of object recognition and spatial memory: heterogeneity of function within the temporal lobe. J Neurosci 24:5901-5908. CrossRef Medline

Woo NH, Duffy SN, Abel T, Nguyen PV (2003) Temporal spacing of synaptic stimulation critically modulates the dependence of LTP on cyclic AMP-dependent protein kinase. Hippocampus 13:293-300. CrossRef Medline

Xia Z, Storm DR (2005) The role of calmodulin as a signal integrator for synaptic plasticity. Nat Rev Neurosci 6:267-276. CrossRef Medline

Yang HW, Lin YW, Yen CD, Min MY (2002) Change in bi-directional plasticity at CA1 synapses in hippocampal slices taken from 6-hydroxydopaminetreated rats: the role of endogenous norepinephrine. Eur J Neurosci 16:11171128. CrossRef Medline

Zhong H, Sia GM, Sato TR, Gray NW, Mao T, Khuchua Z, Huganir RL, Svoboda K (2009) Subcellular dynamics of type II PKA in neurons. Neuron 62:363-374. CrossRef Medline 